\title{
周波数領域ランキンパネル法における無限遠条件の 数值処理について
}

\author{
正会員 岩下 英嗣 ${ }^{*}$ \\ On Numerical Treatments of the Infinite Condition in the Frequency-Domain Rankine Panel Method \\ by Hidetsugu Iwashita, Member
}

\begin{abstract}
Summary
The frequency-domain Rankine panel method is one of the practical tool to estimate ship seakeeping. Although several numerical infinite conditions which are essential in the method have been proposed by many researchers around 1990, there still remains an unsettled problem on how to satisfy the infinite condition accurately in low-speed and/or low-frequency range where $\tau=U \omega_{e} / g$ takes small values. Recently Das et al. ${ }^{10)}$ and Yuan et al. ${ }^{11)}$ proposed a Sommerfeld-type radiation condition for that problem from a concept of the Doppler shift on ring waves. In this paper, we originally derive a general form of the Sommerfeld-type radiation condition applying the asymptotic wave theory. The result indicates irrational points of their method and leads us to a more accurate method. The proposed method is validated by solving the wave field generated by a point source and by comparing with other methods with different numerical infinite conditions. Then we confirm that the present method is the most accurate and also effective for the actual ship seakeeping problem.
\end{abstract}

\section{1. 緒 言}

船舶の耐航性能推定法の一つとして周波数領域ランキンパネル 法がある。1990 年前後に多くの研究者により各種の計算法が 提案されているが、その違いは主として数值的な無限遠条件の 満足のさせ方にある。ここで言う無限遠条件とは、物理的に不 適切な進行波を取り除き、適切な進行波のみを無限遠へ伝播さ せることで、結果として物理的に適切な波動場を得るための 条件のことであり、放射条件や波無し条件等を包含している。 Bertram $^{1)}$ は安東ら ${ }^{2)}$ や Jensen $ら^{3)}$ が定常問題で提案した パネルシフト法を非定常問題に適用している。これは間接法に 基づく定式化において、自由表面上の境界条件を課す選点を 自由表面パネルに対して上流側に 1 パネル分シフトさせるこ とで無限遠条件を満足させる方法であり、造波が下流域に起 こる場合にのみ適用できる。Sclavounos \& Nakos ${ }^{4)}$ は直接法 に基づく定式化において、自由表面上の速度ポテンシャル分 布をスプライン関数で表し、上流端に二重の条件を課すこと で無限遠条件を満足する方法を提案している。この方法もま た、造波が下流域に起こる場合にのみ有効な方法である。国外 の研究が、無次元パラメーター $\tau \equiv U \omega_{e} / g\left(U\right.$; 船速, $\omega_{e}$; 出会 い円周波数, $g$; 重力加速度) が比較的大きい領域、すなわち造 波が下流域に限定される高速/高周波数域を対象とした方法の 提案であるのに対して、国内では $\tau$ が小さくなる低速/低周波

\footnotetext{
* 広島大学大学院工学研究院
}

原稿受理 平成 28 年 3 月 1 日
数域での無限遠条件に着目した研究が行われている。高木 ${ }^{5}$ は自由表面条件に Rayleigh の仮想摩擦係数を数值的に導入し て計算することで無限遠条件を満足する方法を提案している。 安川 ${ }^{6)}$ は、定常問題で Dawson ${ }^{7)}$ が用いた上流差分法により Kelvin 型の波形である $k_{1}$ 波成分の無限遠条件を、また高木の 提案した数值仮想摩擦係数により円環型波形である $k_{2}$ 波成分 の無限遠条件を満足させる方法を提案している $\left(k_{1}, k_{2}\right.$ につい ては 4.1 節 (22) 式参照)。その他に岩下ら ${ }^{8)}$ による結合境界 積分方程式法 (ハイブリッド法) もある。これら各種方法の詳 細はシンポジウムテキストでも紹介されている9)。

実船の耐航性能では、まずは正面向い波中での性能が重視 されることもあり、上記種々の方法は、これまで向い波を主と して適用されてきた経緯がある。向い波は実験データが豊富で あることから多くの比較検証も行われてきている。いずれの方 法も、斜波中や追い波など $\tau$ が小さい領域で無限遠条件の満 足精度に問題を残していることは認識されていたが、その問題 解決は放置されたまま、時代は時間領域計算法の開発へと移つ て行った。昨今の EEDI の関係で、斜波中を含めた波浪中抵 抗増加の高精度推定が望まれるようになった状況下で、時間領 域解法よりも遥かに計算負荷の低い周波数領域解法による推定 精度向上が望まれて来ている。そのためには、低速/低周波数 域など $\tau$ の值が小さい領域においても、無限遠条件を高精度 で満足できる解法の提案が必要である。

本論文では、厳密解を得ることができるという理由から、単 一特異点まわりの流場を求める境界值問題を取り上げる。まず 
はそれを既存の計算法により解き、厳密解と比較することで 問題点等を抽出する。続いて無限遠条件として漸近波理論か ら Sommerfeld 型放射条件を導き、それを拡張することで精 度良く無限遠条件を満足できる方法を検討する。Sommerfeld 型放射条件は、最近 Das ら 10) やYuan ら 11)により円環波 のドップラーシフトの概念から提案された方法であるが、漸 近波理論の視点から導出し直すことで考察を深めることがで きるとともに、そこからさらに良い条件の検討が可能となる。 最後に、実船を含めた計算例を示すことで、本論文で提案する 方法の検証を行っている。

\section{2. 各種計算法の定式化}

本論文で計算に使用する各種基本計算法についてその定式化を 行っておく。使用する座標系として一定速度で前進する船舶を 考え、船体と共に前進する等速移動座標系を取る。船体中央の 船体中心線静水面上を原点とし、前進方向に $x$ 軸、鉛直上向き に $z$ 軸を取った右手系座標系である。流体領域を取り囲む境界 面を考える場合には法線は流体内向き法線を正として考える。

船長 $L$ の船体を代表する周期的特異点 (単位強さ) が船体中 央静水面下 $\mathrm{Q}_{0}=\left(0,0, z_{0}^{\prime}\right)\left(z_{0}^{\prime}=-L / 10\right)$ にあるとする。扱 う境界值問題は Neumann-Kelvin 型の自由表面問題とする。

\section{1 厳密解}

点 $Q_{0}$ に置かれ Neumann-Kelvin 型自由表面条件を満足す る単位強さの周期的特異点 (吸い込み点) まわりの流場を表す 速度ポテンシャル $\operatorname{Re}\left[G_{W} e^{i \omega_{e} t}\right]$ ( $\omega_{e}$; 出会い円周波数) は、い わゆる前進速度ありのグリーン関数 (波核関数) であり、

$$
G_{W}(\mathrm{P} ; \mathrm{Q})=\frac{1}{4 \pi}\left(\frac{1}{r}-\frac{1}{r^{\prime}}\right)+T(X, Y, Z), \quad Q=Q_{0}
$$

の形で表せる。ここで、 $\mathrm{P}=(x, y, z), \mathrm{Q}=\left(x^{\prime}, y^{\prime}, z^{\prime}\right)$ であり、

$$
\left.\begin{array}{c}
r \\
r^{\prime}
\end{array}\right\}=\sqrt{\left(x-x^{\prime}\right)^{2}+\left(y-y^{\prime}\right)^{2}+\left(z \mp z^{\prime}\right)^{2}}
$$

である。 $T(X, Y, Z)=T\left(x-x^{\prime}, y-y^{\prime}, z+z^{\prime}\right)$ は波動項で あり、たとえば別所の一重積分表示式 12)13）で表せ、その高 速高精度計算法は既に確立されている ${ }^{14)}$ 。 $G_{W}$ の満足する Neumann-Kelvin 型の自由表面条件式は、偏微分演算子

$$
\begin{aligned}
& \mathcal{L} \equiv-K_{e}-2 i \tau \frac{\partial}{\partial x}+\frac{1}{K_{0}} \frac{\partial^{2}}{\partial x^{2}}+\frac{\partial}{\partial z}+i \mu K_{e}-\mu \tau \frac{\partial}{\partial x} \\
& \text { ただし、 } K_{e}=\omega_{e}^{2} / g, \quad \tau=U \omega_{e} / g, \quad K_{0}=g / U^{2}
\end{aligned}
$$

を定義するとき、

$$
\lim _{\mu \rightarrow 0} \mathcal{L}\left[G_{W}\left(\mathrm{P}, \mathrm{Q}_{0}\right)\right]=0 \quad \text { on } z=0
$$

で表される。(3) の $\mu$ は無限遠条件を満足させるために導入さ れた Rayleigh の仮想摩擦係数であり、 $G_{W}$ は無限遠条件を解 析的に満足している。

\section{2 パネルシフト法}

単一特異点まわりの流場をランキンパネル法で求めるため の定式化を示しておく。特異点まわりの流場を表す速度ポテン シャルを $\operatorname{Re}\left[\phi(\mathrm{P}) e^{i \omega_{e} t}\right]$ とするとき、 $\phi(\mathrm{P})$ は自由表面 $\left(S_{F}\right)$ 上の吹き出し分布 $\sigma(\mathrm{Q})$ を用いて

$$
\phi(\mathrm{P})=G_{0}\left(\mathrm{P}, \mathrm{Q}_{0}\right)-\iint_{S_{F}} \sigma(\mathrm{Q}) G(\mathrm{P}, \mathrm{Q}) d S
$$

と表すことができる。ただし、

$$
G_{0}\left(\mathrm{P}, \mathrm{Q}_{0}\right)=\frac{1}{4 \pi}\left(\frac{1}{r}+\frac{1}{r^{\prime}}\right), \quad G(\mathrm{P}, \mathrm{Q})=\frac{1}{4 \pi r}
$$

である。 $\phi(\mathrm{P})$ の満足しなくてはならない自由表面条件 $\mathcal{L}[\phi(\mathrm{P})]=$ 0 に代入することにより、吹き出し分布に関する積分方程式 $\iint_{S_{F}} \mathcal{L}[G(\mathrm{P}, \mathrm{Q})] \sigma(\mathrm{Q}) d S=\mathcal{L}\left[G_{0}\left(\mathrm{P}, \mathrm{Q}_{0}\right)\right]_{\mu=0} \quad$ for $\mathrm{P} \in S_{F}$

を得る。ただし、 $\mathrm{P}=\mathrm{Q}$ の時に現れる核の特異性に起因する 項 $\sigma(\mathrm{P}) / 2$ は、(7) を離散化して計算する際に左辺の積分から 自動算出されるとして表記上除いている。本論文では (7) を一 定要素で離散化して解くことにより最終的に特異点まわりの流 場を求めている。

パネルシフト型のランキンパネル法では、Fig. 1(a) に示す ように自由表面条件を満足させる選点を上流側に 1 パネル分

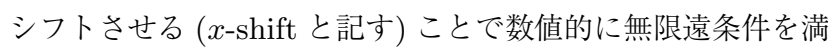
足する。一般には (3) の $\mu$ をゼロとして計算する。瀬戸 ${ }^{18)}$ に より、2 次元問題においてはパネルシフトが効率的な上流差分 に相当することが証明されている。造波が下流域に起こる場合 にのみ有効な方法である。

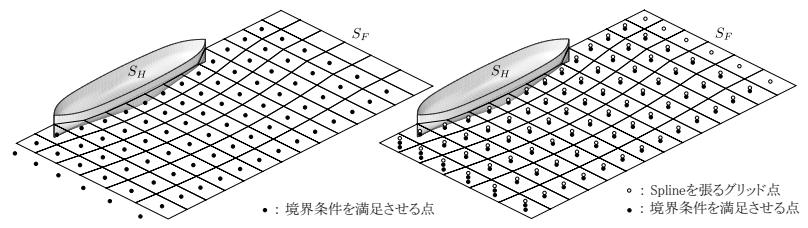
(a) Panel shift
(b) Spline

Fig. 1 Collocation points of panel shift method and spline method

\section{3 上流差分法}

定常問題において Dawson ${ }^{7)}$ により提案された上流差分法 では、速度ポテンシャル $\phi$ の 2 階偏微分 $\phi_{x x}$ を $\phi$ から差分近 似計算することにより無限遠条件を満足させる。いま、自由表 面上の任意点を $\mathrm{P}_{j}$ とするとき、 $\phi_{x x}\left(\mathrm{P}_{j}\right)$ をその上流側に存在 する $\mathrm{P}_{j+1}, \mathrm{P}_{j+2}, \mathrm{P}_{j+3}$ のを用いて、差分式

$$
\begin{aligned}
\phi_{x x}\left(\mathrm{P}_{j}\right)=\frac{1}{\Delta x^{2}}\{ & -\phi\left(\mathrm{P}_{j+3}\right)+4 \phi\left(\mathrm{P}_{j+2}\right) \\
& \left.-5 \phi\left(\mathrm{P}_{j+1}\right)+2 \phi\left(\mathrm{P}_{j}\right)\right\}+O\left(\Delta x^{2}\right)
\end{aligned}
$$


により計算する。 $\Delta x$ は $x$ 軸方向に等間隔に格子が分割され ていた場合の計算点の間隔 $\left|\mathrm{P}_{j+1}-\mathrm{P}_{j}\right|$ である。積分方程式は (7) と同様に

$$
\begin{array}{r}
\iint_{S_{F}} \mathcal{L}\left[G\left(\mathrm{P}_{j}, \mathrm{Q}\right)\right] \sigma(\mathrm{Q}) d S=\mathcal{L}\left[G_{0}\left(\mathrm{P}_{j}, \mathrm{Q}_{0}\right)\right]_{\mu=0} \\
\text { for } \mathrm{P}_{j} \in S_{F}
\end{array}
$$

となるが、左辺に現れる $G_{x x}$ は $(8)$ の関係を用いて次式によ り計算することになる。

$$
\begin{array}{r}
G_{x x}\left(\mathrm{P}_{j}, \mathrm{Q}\right)=\frac{1}{\Delta x^{2}}\left\{-G\left(\mathrm{P}_{j+3}, \mathrm{Q}\right)+4 G\left(\mathrm{P}_{j+2}, \mathrm{Q}\right)\right. \\
\left.-5 G\left(\mathrm{P}_{j+1}, \mathrm{Q}\right)+2 G\left(\mathrm{P}_{j}, \mathrm{Q}\right)\right\}
\end{array}
$$

差分次数については上記の 4 点差分が比較的良好な結果を与 えるとされている。この方法も、造波が下流域に起こる場合に のみ有効な方法であり、一般には (3) の $\mu$ をゼロとして計算 する。

\section{4 スプライン要素法}

Sclavounos \& Nakos ${ }^{4}$ ににより提案された通称スプライン要 素法は直接法に基づいており、元になる積分方程式は

$$
\begin{aligned}
\frac{\phi(\mathrm{P})}{2}-\iint_{S_{F}}\{ & \frac{\partial G(\mathrm{P}, \mathrm{Q})}{\partial n_{\mathrm{Q}}} \phi(\mathrm{Q}) \\
& \left.-\frac{\partial \phi(\mathrm{Q})}{\partial n_{\mathrm{Q}}} G(\mathrm{P}, \mathrm{Q})\right\} d S=G\left(\mathrm{P}, \mathrm{Q}_{0}\right)
\end{aligned}
$$

となる。自由表面を $N$ 個のパネルに分割し、その上の速度ポ テンシャル分布をスプライン関数 $B_{m}(\mathrm{Q})$ を用いて

$$
\phi(\mathrm{Q})=\sum_{m=1}^{N} \lambda_{m} B_{m}(\mathrm{Q})
$$

と表す。(3) から $z$ 偏微分項を除き、 $x$ を $x^{\prime}$ に変えた演算子 を新たに $\mathcal{L}_{2}$ と書くことにすると、自由表面条件式から

$$
\frac{\partial \phi(\mathrm{Q})}{\partial n_{\mathrm{Q}}}=-\frac{\partial \phi(\mathrm{Q})}{\partial z^{\prime}}=\sum_{m=1}^{N} \lambda_{m} \mathcal{L}_{2}\left[B_{m}(\mathrm{Q})\right]
$$

を得る。(12), (13)を(11) に代入して、一定要素の仮定で離 散化すると次の方程式を得る。

$$
\begin{aligned}
-\sum_{m=1}^{N} \lambda_{m} \sum_{j=1}^{N}\{ & B_{m}\left(\mathrm{Q}_{j}\right) F_{1}\left(\mathrm{P}_{i}, \Delta S_{j}\right) \\
& \left.-\mathcal{L}_{2}\left[B_{m}\left(\mathrm{Q}_{j}\right)\right] F_{2}\left(\mathrm{P}_{i}, \Delta S_{j}\right)\right\}=G\left(\mathrm{P}_{i}, \mathrm{Q}_{0}\right)
\end{aligned}
$$

ただし、

$$
\left.\begin{array}{l}
F_{1}\left(\mathrm{P}_{i}, \Delta S_{j}\right)=\iint_{\Delta S_{j}} \frac{\partial G\left(\mathrm{P}_{i}, \mathrm{Q}\right)}{\partial n_{\mathrm{Q}}} d S \\
F_{2}\left(\mathrm{P}_{i}, \Delta S_{j}\right)=\iint_{\Delta S_{j}} G\left(\mathrm{P}_{i}, \mathrm{Q}\right) d S
\end{array}\right\}
$$

(15) は $j$ 番目のパネル $\Delta S_{j}$ 内での核関数の $Q$ に関する積分 を表している。(12)のスプライン関数近似における代表点は Fig. 1(b) の白丸点である。一方、境界条件を満足させる点は
黒丸点であり、一番上流は二重条件とするのがこの方法のポイ ントとなる。その二重条件には

$$
\left(i K_{e}-\tau \frac{\partial}{\partial x}\right) \phi(\mathrm{P})=0, \quad\left(i K_{e}-\tau \frac{\partial}{\partial x}\right)^{2} \phi(\mathrm{P})=0
$$

を課し、これが無限遠条件 (陽な形で表された波無し条件) と なる。最初の条件式は波の隆起量 $\zeta$ がゼロであるという力学 的条件に相当し、後者は運動学的条件 $\partial \phi / \partial z=\partial \zeta / \partial t=0$ で ある。これら無限遠条件も下流域にのみ造波が起こる場合に適 用可能な条件である。一般には $\mathcal{L}_{2}$ 内の $\mu$ はゼロとして計算 する。

\section{3. 各種計算法の特徵}

\section{1 計算法の比較}

無限遠条件の満足のさせ方の違いによる 3 種類のランキン

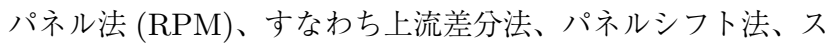
プライン要素法を比較して特徵や問題点を抽出する。

$F_{n}=U / \sqrt{g L}=0.2$ とし、異なる $K_{e} L=\omega_{e}^{2} L / g$ の值に対 して得られた各種計算法による $z=0$ 上の速度ポテンシャルの 実部 $\operatorname{Re}[\phi]$ の分布図を Fig. $2 \sim 6$ に示している。 $K_{e} L$ の変化 に応じて $\tau$ の值が変化し、特異点まわりの波動場が変化する 様子が分かる。各図中、(a) は漸近波紋図、(b) は厳密解、(c) は上流差分法、(d) はパネルシフト法、(e) はスプライン要素 法の結果である。漸近波紋図においては、図を見やすくするた めに、最も波長の短い $k_{1}$ 波 (4.1 節の (22) 式参照) の波紋図 を負の $y$ 軸側に描いている。また波紋図の色は後述の Fig. 10 における各波系に対応している。漸近波紋図中で陰影を施した 部分が $(\mathrm{b}) \sim(\mathrm{e})$ における計算領域を示している。計算領域は、 船舶の計算 (向い波) をする場合に通常用いられるアスペクト 比 (計算領域縦横比 0.6) くらいにしており、 $x$ 軸方向に 80 分 割、 $y$ 軸方向に 32 分割 ( $y$ が増大するに従い格子が粗になる) している。もちろん (b)〜 (e) では同じ計算格子を用いている。 各計算法の波動場の相違を見易くする目的から、鳥瞰図は等 高線図を斜め上流側から見た図にしている点に注意されたい。 鳥瞰図中の座標軸は $z$ 軸上方へシフトして描いている。つま り特異点は描かれた $z$ 軸を下方へ延長した位置にある。上流 の矢印は一様流の向きを表している。

Fig. 2 は $\tau$ が十分に大きく、造波が計算領域内に完全に収 まっている場合に相当する。全体的にみると厳密解に比べて各 種計算法の合致は悪くはない。しかし、詳細に見てみると次の ようなことが分かる。座標原点から、造波された波のカスプ点 を連ねた直線を引いてカスプ角を見てみると、上流差分および パネルシフト法の結果はその角度が厳密解と比べてかなり大 きくなっていることが分かる。また、 $x$ 軸後方の波の波頂位置 に着目すると、位相が上流側へずれている。こうした現象は、 パネルシフト法を用いた実船の計算波形と計測波形との比較 においても以前より高周波数域 $(\tau$ が大きい周波数域 $)$ で確認 されている15)。図から分かるように、この現象はスプライン 要素法ではほとんど見られない。カスプ角については、Fig. 3 の計算領域端を見るとより分かり易いであろう。 $x$ 軸方向の波 


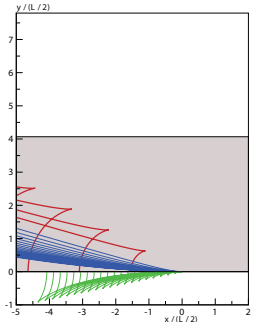

(a) Asymptotic wave pattern

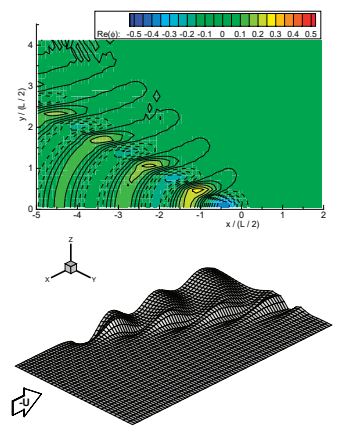

(b) Wave source
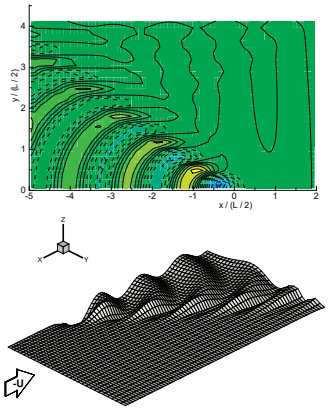

(c) Upwind
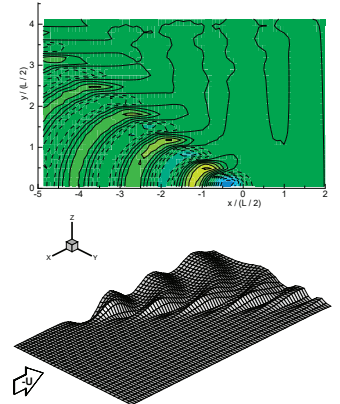

(d) Panel shift

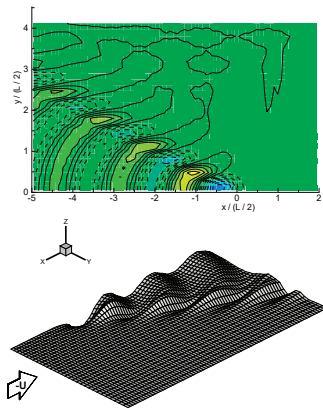

(e) Spline

Fig. 2 Distribution of $\operatorname{Re}[\phi]$ by RPMs with different numerical infinite condition for $F_{n}=0.2, K_{e} L=20, \tau=0.894$

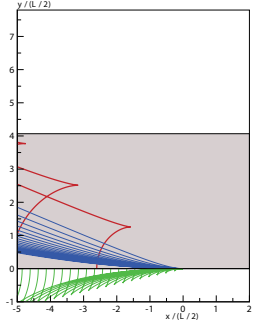

(a) Asymptotic wave pattern
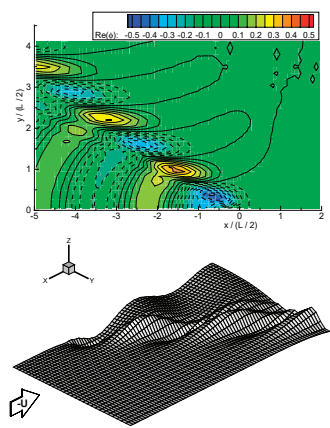

(b) Wave source
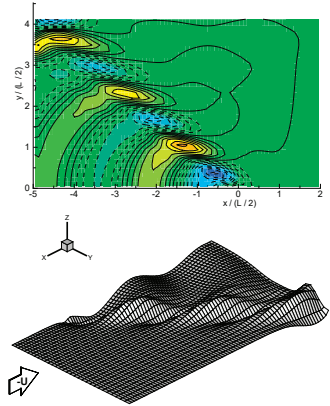

(c) Upwind
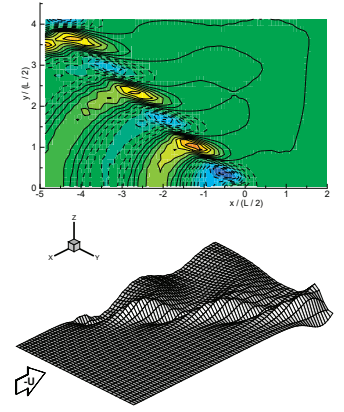

(d) Panel shift
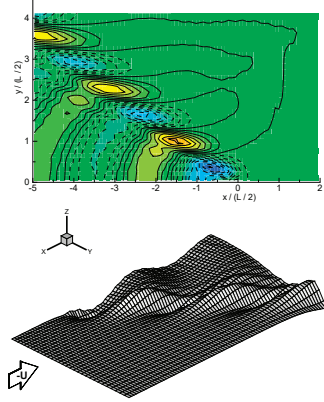

(e) Spline

Fig. 3 Distribution of $\operatorname{Re}[\phi]$ by RPMs with different numerical infinite condition for $F_{n}=0.2, K_{e} L=10, \tau=0.632$

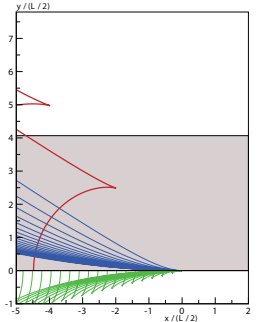

(a) Asymptotic wave pattern
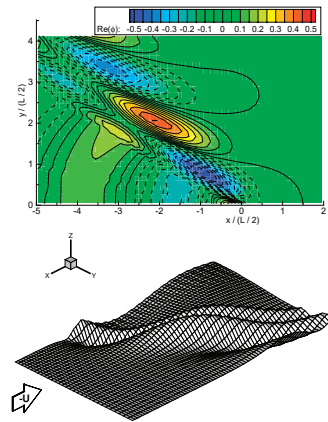

(b) Wave source
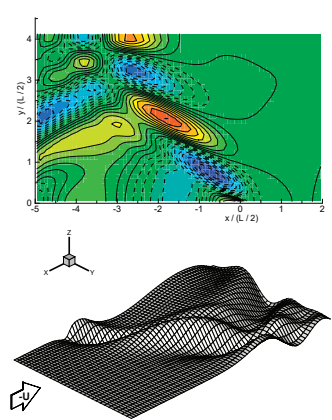

(c) Upwind
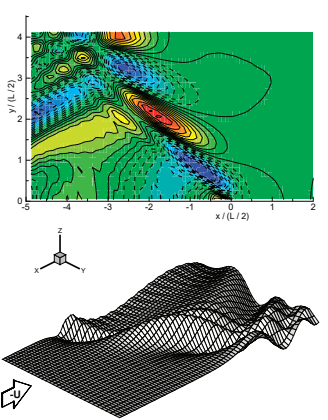

(d) Panel shift

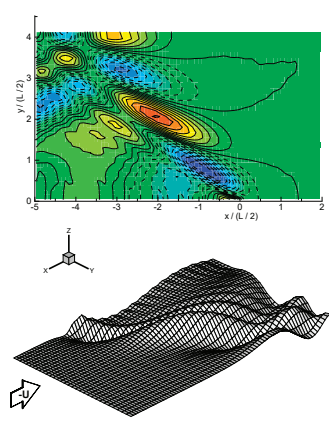

(e) Spline

Fig. 4 Distribution of $\operatorname{Re}[\phi]$ by RPMs with different numerical infinite condition for $F_{n}=0.2, K_{e} L=5, \tau=0.447$

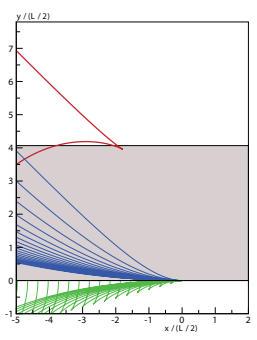

(a) Asymptotic wave pattern

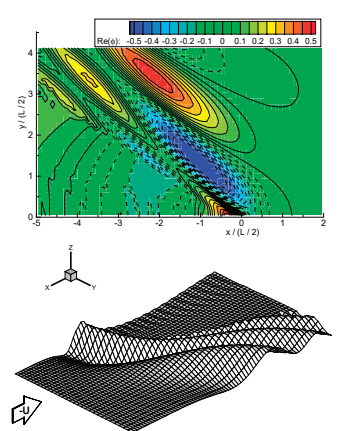

(b) Wave source
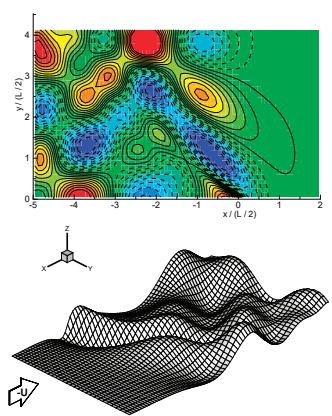

(c) Upwind
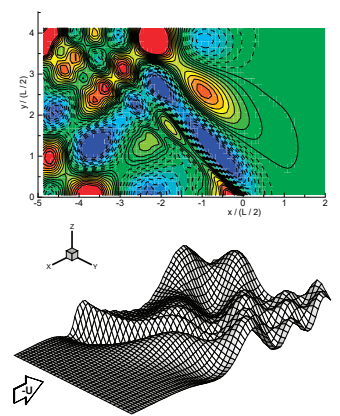

(d) Panel shift

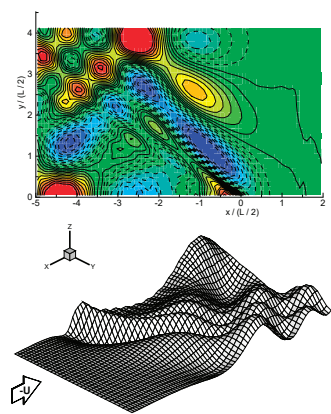

(e) Spline

Fig. 5 Distribution of $\operatorname{Re}[\phi]$ by RPMs with different numerical infinite condition for $F_{n}=0.2, K_{e} L=3, \tau=0.346$ 


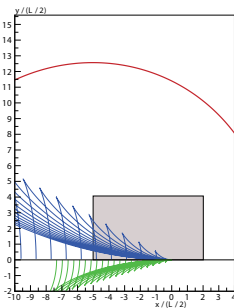

(a) Asymptotic wave pattern
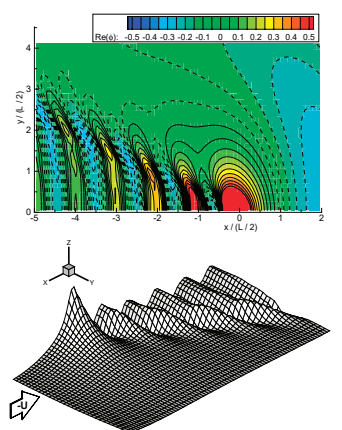

(b) Wave source
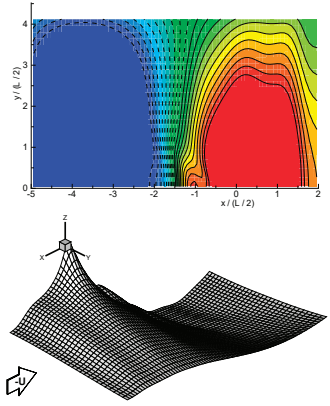

(c) Upwind
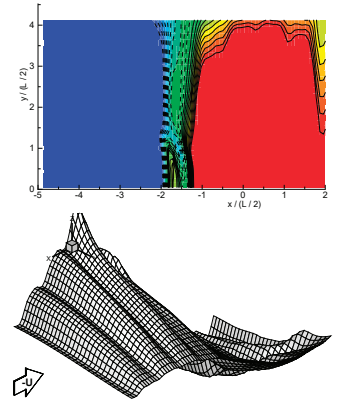

(d) Panel shift
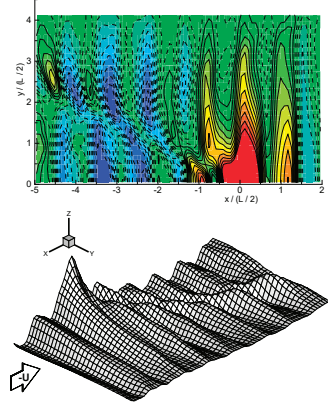

(e) Spline

Fig. 6 Distribution of $\operatorname{Re}[\phi]$ by RPMs with different numerical infinite condition for $F_{n}=0.2, K_{e} L=1, \tau=0.2$
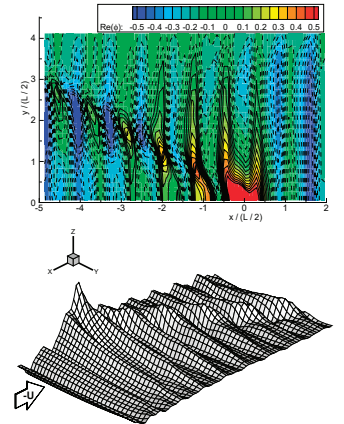

(a) $\zeta=0,2$ nd eq. in (16)
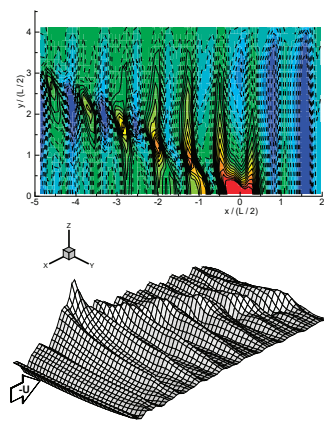

(b) $\zeta=0, \phi_{z}=0$
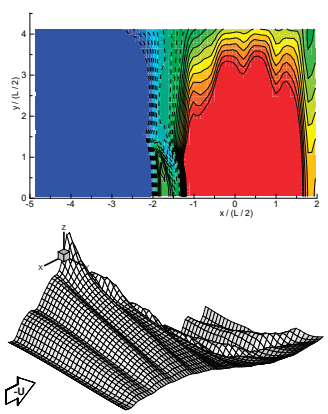

(c) $S_{F}$ condi., $\phi_{z}=0$
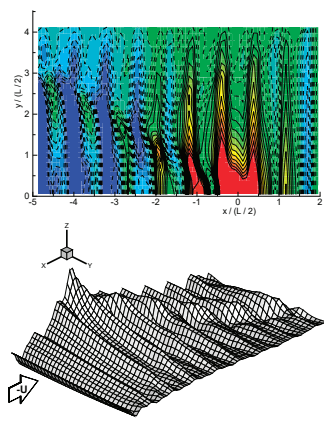

(d) $S_{F}$ condi., $\zeta=0$

Fig. 7 Effect of additional conditions at overlapped end-points for $F_{n}=0.2, K_{e} L=1, \tau=0.2$

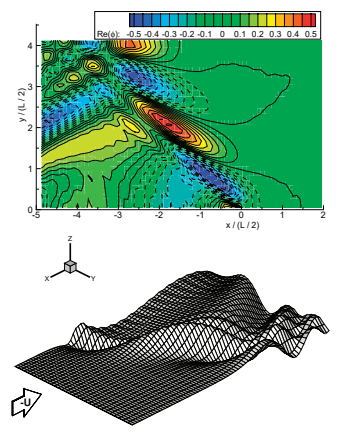

(a) $\zeta=0,2$ nd eq. in $(16)$

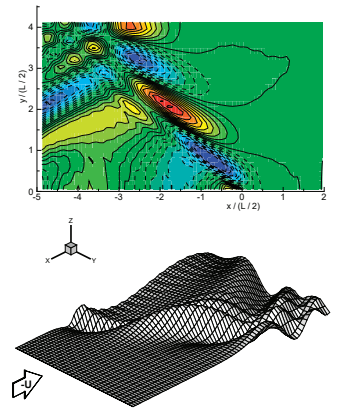

(b) $\zeta=0, \phi_{z}=0$

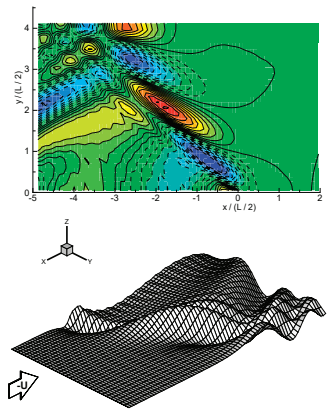

(c) $S_{F}$ condi., $\phi_{z}=0$

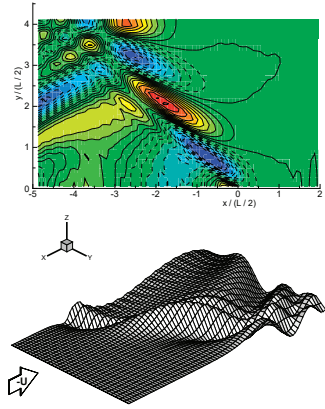

(d) $S_{F}$ condi., $\zeta=0$

Fig. 8 Effect of additional conditions at overlapped end-points for $F_{n}=0.2, K_{e} L=5, \tau=0.447$

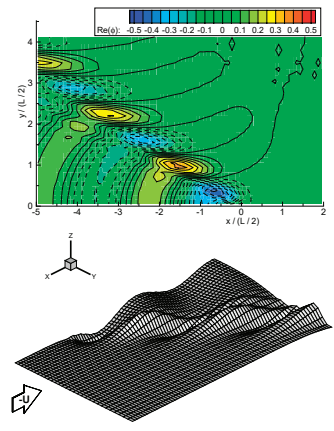

(a) Wave source

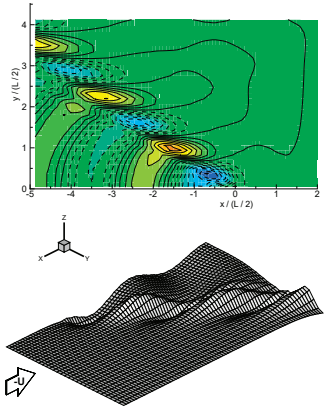

(b) with $z$-shift
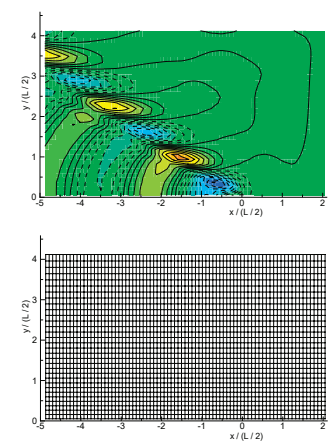

(c) with uniform grid
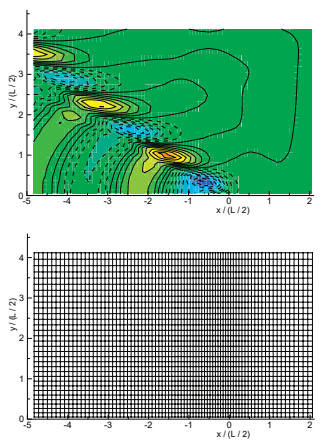

(d) with nonuniform grid

Fig. 9 Enhanced panel shift method adding $z$-shift and with nonuniform grid for $F_{n}=0.2, K_{e} L=10, \tau=0.632$ 
長が短くなってしまう現象については Figs. 2, 3 の比較から $\tau$ が大きくなるほど顕著となっていることが分かる。

Fig. 4 の $\tau$ になると、造波された波が計算領域幅方向の端 に掛かるようになり、あたかも壁からの反射のような波動が見 られるようになる。この現象は Fig. 5 のように $\tau$ がより小さ くなるに従い顕著化するが、Fig. 6 のように $\tau<0.25$ となり $k_{2}$ 波が円環波系になると異なる様相を示すようになる。計算 領域端からの反射波は見られなくなるが、波動場が不自然とな る。スプライン要素法は他の方法に比べれば良い結果を与えて いる。これは次節に示すように条件 (16) に関連していると思 われる。

Figs. $2 \sim 6$ の全体を見ると、上流差分法は波振幅をやや小 さく推定していることなどが分かる。Fig. 5 の厳密解や他の計 算法による結果には現れている波長の短い $k_{1}$ 波などが上流差 分法の結果には現れていない。差分法による短波長波の分解能 が十分でないことが原因であろう。以上をまとめると、次の知 見が得られたことになる。

i. スプライン要素法、パネルシフト法の順番で計算精度が 良い。差分法は同じ計算格子を用いた場合、短波長波の 分解能が劣る。

ii. パネルシフト法はカスプ角や波の位相ずれに関する不具 合が解決されればスプライン要素法と同等の方法となる。

iii. いずれの方法でも計算領域幅方向の端に造波された波が 掛かるような $\tau$ になると、反射波など無限遠条件が満足 されていない現象が生じる。

\section{2 パネルシフト法とスプライン要素法の関係}

ここで、パネルシフト法とスプライ要素法との関係につい て考えてみる。前者は間接法であり、Fig. 1(a)のように境界 条件を課す選点を上流側へ 1 パネル分シフトさせる。後者は 直接法であり、Fig. 1(b) のように上流端で二重条件を課すた めに境界条件を課す選点をやはり上流側にシフトさせることに なる。つまり両者は境界条件を合わせる選点を 1 パネル分上 流側にシフトさせる点では同じことを行っていることになる。 つまりスプライ要素法もパネルシフト法の仲間である。スプラ イン関数は単に自由表面上の速度ポテンシャル分布を表現する ために導入されただけで、この関数の導入自体に無限遠条件を 満足する効果があるわけではない。両者の違いは、上流端で二 重条件を課すか否かにある。そこで、パネルシフト法におい ても、Fig.1(b)のように上流端で点を重ね、二重条件を課し て計算してみると、その結果は Figs. 7, 8 のようになる。各々 $\tau=0.2,0.447$ に対する結果である。各図中の $(\mathrm{a}) \sim(\mathrm{d})$ は上 流端に課した二重条件に下記のような違いがある。
(a) : (16) の第 1 式と第 2 式
(b) : (16)の第 1 式と $\phi_{z}(\mathrm{P})=0$
(c) $: \mathcal{L}[\phi(\mathrm{P})]=0$ と $\phi_{z}(\mathrm{P})=0$
$(\mathrm{d}): \mathcal{L}[\phi(\mathrm{P})]=0$ と $(16)$ の第 1 式

前記のように、(16) の第 1 式は $\zeta=0$ の条件を意味している。 まず、Fig. 7 について見てみる。(a) と (b) に課した二重条 件は同じ意味なので両者の結果はほぼ同じ結果になっている。 (a) は Fig. 6(e) のスプライン要素法と同じ条件を課して得ら れたパネルシフト法の結果になる。両者にはそれなりの相違が 見られるが、それは直接法と間接法など定式化の相違に因るも のであろう。(c) の結果は Fig. 6(d) のオリジナルのパネルシ フト法の結果とほぼ同じ結果になっている。オリジナルのパネ ルシフト法は上流端で点を重ねずに、通常の自由表面条件を 課すだけであるが、その効果は、上流端で点を重ねて自由表 面条件と $\phi_{z}=0$ の条件を二重に課した結果と同等であるとい うことになる。このように、自由表面条件と $\phi_{z}=0$ の二重条 件では厳密值と比べて全く異なる結果になるのに対して、(d) のように自由表面条件と (16) の第 1 式を二重条件として課す と、スプライン要素法レベルの結果に改善されることも分か る。(16)の第 1 式は力学的条件に相当するので、この条件を 課すことが数值解の改善に対して重要であることが分かる。

Fig. 8 は $\tau=0.447$ の結果であるが、上流端の二重条件の 相違による影響はほとんどないと言ってよい。以上をまとめる と下記のようになる。

iv. パネルシフト法とスプライン要素法は境界条件を課す選 点を上流側にシフトする意味で全く同じものである。

v. パネルシフト法において上流端点を重ね、スプライン要素 法と同じ (16) を二重条件として課すとスプライン要素法 と同等の結果を得る。ただし、 $\tau>1 / 4$ の Fig. 8 は良いと して、 $\tau<1 / 4$ となる Fig.7 の場合には、条件 (16) が不 適切となり、二重条件を課したパネルシフト法、スプライ ン要素法ともに計算精度が良いわけではない。 $\tau<1 / 4$ の 場合に課すべき二重条件については 4.6 節で議論される。

vi. 上流端点に二重条件を課すパネルシフト法によりオリジ ナルのパネルシフト法相当の結果を得たければ、二重化 した上流端点に $\mathcal{L}[\phi(\mathrm{P})]=0$ と (16) の第 2 式を課せば よい。

\section{3 パネルシフト法の改良}

3.1 節に示したように、パネルシフト法にはカスプ角が大き くなり、波長が短くなるという問題点がある。今回、多くの試 計算を通じてこれを改善する方法が見出された。その方法は 意外にも単純で、吹き出し分布面を $z$ 軸正方向に $x$ 軸方向へ のシフト量と同じ程度シフトさせるというものである。吹き 出し面を $z$ 軸正方向ヘシフトさせる方法 ( $z$-shift と記す) は、 かつて Cao ら 16)17) が提案した desingularized method であ る。元々は核関数の計算において解析積分を行うのを回避する と共に非線形自由表面問題を解く目的で提案されたものであ るが、今回それが波動場推定の改善に寄与することが見出さ れた。Fig. 9(b)に結果の一例を示している。(a) の厳密解やオ リジナルの Fig. 3(d) と比べて、カスプ角および $x$ 軸後方の波 の位相が正確なものに改善されている。 $z$ 軸方向へのシフト量 は、小さければカスプ角の修正量が不十分、大きければ波の隆 
起量が小さくなる、などの傾向があり $x$ 軸方向のシフト量と 同程度が最良であった。ただし、この $z$-shift の有効性につい ては、試行錯誤の数值試験の末に得られた知見であり数理的裏 付けがあるわけではない。

もう一つ見出されたことがある。これまでパネルシフト法 では $x$ 軸方向へのパネル分割を等間隔で行わなくてはならな いものとされて来ていた。これは 2 次元定常問題において等 間隔格子を用いたパネルシフト法が提案されて以降の慣習的 なものかも知れない。しかし、実際には、パネルをある箇所 に引き寄せて計算しても計算結果は変化しない。Fig. 9(c)に (b) の結果を格子図と共に再度示している。これに対し (d) は、 $-2<x /(L / 2)<2$ の範囲で原点に向かって計算格子を引き寄 せて得られた結果である。両者の計算結果に相違がないこと が確認される。より強い引き寄せ率でも特に問題はない。な お、(c),(d) とも $z$-shift を適用している。計算領域の一部で計 算格子の引き寄せを行う不等間隔格子採用時 (つまり $(\mathrm{d})$ の場 合)の $z$ 軸方向のシフト量は、格子引き寄せを行っていない $-5<x /(L / 2)<-2$ の範囲での $x$ 軸方向パネルサイズと同量 としている。

前節にスプライン要素法もパネルシフト法の一種であるこ とを記した。スプライン要素法では、たとえば船首尾部に自由 表面計算格子を引き寄せるようなことが普通に行われている。 この事実から考えて、パネルシフト法においても計算格子の引 き寄せが可能というのは自然な結論である。

以上に見出された二つの事実は、パネルシフト法を実船に 適用する際に極めて有益である。こうしてスプライン要素法に 比べた場合のパネルシフト法の欠点はなくなり、むしろ数值計 算時に必要とするメモリー数から考えるとパネルシフト法が有 利な方法となる。

\section{Sommerfeld 型放射条件}

以上の計算例に見るように、いずれの方法を用いても、特に計 算領域幅方向の端からの反射波のような現象をなくすことはで きない。基本的にはこの現象を遅らせるべく、幅方向に広い計 算領域を取る必要があろうが、根本的に解決するためには、何 らかの手法により適切に無限遠条件を満足させる必要がある。

その手法の一つとして、高木 ${ }^{5)}$ が提案し、安川 ${ }^{6)}$ が上流 差分法と組み合わせて一般船型に適用した Rayleigh の仮想摩 擦 $\mu$ を数值的に導入する方法がある。他方、計算領域を取り 囲む検査面 $S_{C}$ を追加し、そこに適切な条件を与える方法も考 えられる。そこで、最近 Das ら 10) や Yuan ら 11) が円環波 のドップラーシフトの概念から導出した Sommerfeld 型放射 条件式を漸近波理論から導出し直すことで、一般性を持たせる と共にこの条件式の拡張を図る。

\section{1 漸近波理論を用いた Sommerfeld 型放射条件の導出}

船舶の 3 次元耐航性能理論や漸近波理論は文献 13)にも紹 介されている周知の知識なので、ここでは後述の説明に必要な 概要のみを示す。線形理論で考えるとき、非定常速度ポテン
シャル $\phi$ は一般に diffraction 項と radiation 項に分けて

$$
\phi=\frac{i g \zeta_{a}}{\omega}\left(\varphi_{0}+\varphi_{7}\right)+i \omega_{e} \sum_{j=1}^{6} X_{j} \varphi_{j}
$$

のように表すことができる。 $\zeta_{a}, \omega$ は入射波の波振幅および 円周波数であり、 $X_{j}$ は複素運動振幅、 $\omega_{e}$ は出会い円周波数、 $\varphi_{0}, \varphi_{7}, \varphi_{j}(j=1 \sim 6)$ は各々入射波、diffraction、radiation を表す速度ポテンシャルである。グリーン関数法を用いると、 これら速度ポテンシャルは次式で表すことができる。

$$
\begin{aligned}
& \varphi_{j}(\mathrm{P})=-\iint_{S_{H}} \sigma_{j}(\mathrm{Q}) G_{W}(\mathrm{P}, \mathrm{Q}) d S \\
& +\frac{1}{K_{0}} \oint_{C_{H}} \sigma_{j}(\mathrm{Q}) G_{W}(\mathrm{P}, \mathrm{Q}) n_{x^{\prime}} d y^{\prime} \quad(j=1 \sim 7)
\end{aligned}
$$

$G_{W}$ は $(1)$ で定義されたグリーン関数であり、 $S_{H}$ は静水面下 の船体表面, $C_{H}$ は船体表面と静水面との交線を表している。 遠方場におけるグリーン関数の漸近形を (18) に代入すること で、船から十分に離れた場所の速度ポテンシャルは

$$
\begin{gathered}
\varphi_{j}(\mathrm{P}) \sim \varphi_{j 1}(\mathrm{P})+\varphi_{j 2}(\mathrm{P}) \\
\varphi_{j 1}=-\frac{i}{2 \pi}\left\{\int_{-\pi+\alpha_{0}}^{-\frac{\pi}{2}}-\int_{-\frac{\pi}{2}}^{-\frac{\pi}{2}+\Theta}\right\} \\
H_{j}\left(k_{1}, \theta\right) \frac{k_{1} e^{k_{1} \varpi}}{\sqrt{1+4 \tau \cos \theta}} d \theta \\
\varphi_{j 2}=-\frac{i}{2 \pi} \int_{-\pi+\alpha_{0}}^{-\frac{\pi}{2}+\Theta} H_{j}\left(k_{2}, \theta\right) \frac{k_{2} e^{k_{2} \varpi}}{\sqrt{1+4 \tau \cos \theta}} d \theta
\end{gathered}
$$

と表せる。 $k_{1}, k_{2}, \varpi, \alpha_{0}, \Theta$ は

$$
\begin{aligned}
& \left.\begin{array}{l}
k_{1} \\
k_{2}
\end{array}\right\}=\frac{K_{0}}{2 \cos ^{2} \theta}(1+2 \tau \cos \theta \pm \sqrt{1+4 \tau \cos \theta}) \\
& \varpi=z+i(x \cos \theta+y \sin \theta) \\
& \alpha_{0}= \begin{cases}\cos ^{-1} \frac{1}{4 \tau} & (4 \tau>1) \\
0 & (4 \tau<1)\end{cases} \\
& \Theta=\cos ^{-1}\left(x / \sqrt{x^{2}+y^{2}}\right)
\end{aligned}
$$

であり、 $H_{j}\left(k_{\ell}, \theta\right)(\ell=1,2)$ は次式で定義されるコチン関数 である。

$$
\begin{aligned}
H_{j}\left(k_{\ell}, \theta\right)= & -\iint_{S_{H}} \sigma_{j}(\mathrm{Q}) e^{k_{\ell} \varpi^{\prime}} d S \\
& +\left.\frac{U^{2}}{g} \oint_{C_{H}} \sigma_{j}(\mathrm{Q}) e^{k_{\ell} \varpi^{\prime}}\right|_{z^{\prime}=0} n_{x^{\prime}} d y^{\prime}
\end{aligned}
$$

ただし、

$$
\varpi^{\prime}=z^{\prime}-i\left(x^{\prime} \cos \theta+y^{\prime} \sin \theta\right)
$$

(20), (21) の計算に停留位相法を適用し、 $k_{1}$ 項、 $k_{2}$ 項に関 する各々の積分範囲内に $N_{1}$ および $N_{2}$ 個存在する停留点のう ち $n$ 番目の停留点を $\theta_{1 n}, \theta_{2 n}$ と記すと

$$
\varphi_{j \ell} \sim \sum_{n=1}^{N_{\ell}} \psi_{j}\left(k_{\ell}, \theta_{\ell n}\right) e^{i k_{\ell} \varpi_{0}\left(\theta_{\ell n}\right)} \quad(\ell=1,2)
$$

ただし、

$$
\varpi_{0}(\theta)=x \cos \theta+y \sin \theta
$$


と記せる。ここで、 $\psi_{j}$ は次式で定義される $\theta_{\ell n}$ の関数である。

$$
\psi_{j}\left(k_{\ell}, \theta_{\ell n}\right)=-\frac{i}{2 \pi} \frac{H_{j}\left(k_{\ell}, \theta_{\ell n}\right) k_{\ell} e^{k_{\ell} z}}{\sqrt{1+4 \tau \cos \theta_{\ell n}}} \quad(\ell=1,2)
$$

いま、船体から十分離れた鉛直検査面 $S_{C}$ 上の、ある点での流 体内向き法線ベクトルを $\boldsymbol{n}=\left(n_{1}, n_{2}, 0\right)$ とする。 $\varphi_{j}$ の表示式 $(19) \sim(21)$ における $\varphi_{j 1}, \varphi_{j 2}$ として (28)の停留位相近似式 を用いれば

$$
\nabla \varphi_{j \ell}=\sum_{\ell=1}^{2} \sum_{n=1}^{N_{\ell}}\left[\begin{array}{c}
i k_{\ell} \cos \theta_{\ell n} \\
i k_{\ell} \sin \theta_{\ell n} \\
k_{\ell}
\end{array}\right] \psi_{j}\left(k_{\ell}, \theta_{\ell n}\right) e^{i k_{\ell} \varpi_{0}\left(\theta_{\ell n}\right)}
$$

となるから、鉛直検査面上での法線微分については次式のよう にまとめられる。

$$
\begin{array}{r}
\frac{\partial \varphi_{j \ell}}{\partial n}=\boldsymbol{n} \cdot \nabla \varphi_{j \ell}=\sum_{\ell=1}^{2} \sum_{n=1}^{N_{\ell}} \\
i k_{\ell}\left(n_{1} \cos \theta_{\ell n}+n_{2} \sin \theta_{\ell n}\right) \\
\times \psi_{j}\left(k_{\ell}, \theta_{\ell n}\right) e^{i k_{\ell} \varpi_{0}\left(\theta_{\ell n}\right)}
\end{array}
$$

一般に $k_{1}$ は $k_{2}$ と比べて值が大きく波長が短いので、(32) は $\ell=2$ のみ考えれば十分であると考えられる $\left(\psi_{j}\right.$ には指数関数 が入っており、 $k_{j}$ が大きいと $\psi_{j}$ が小さな值となって寄与が小 さくなる)。
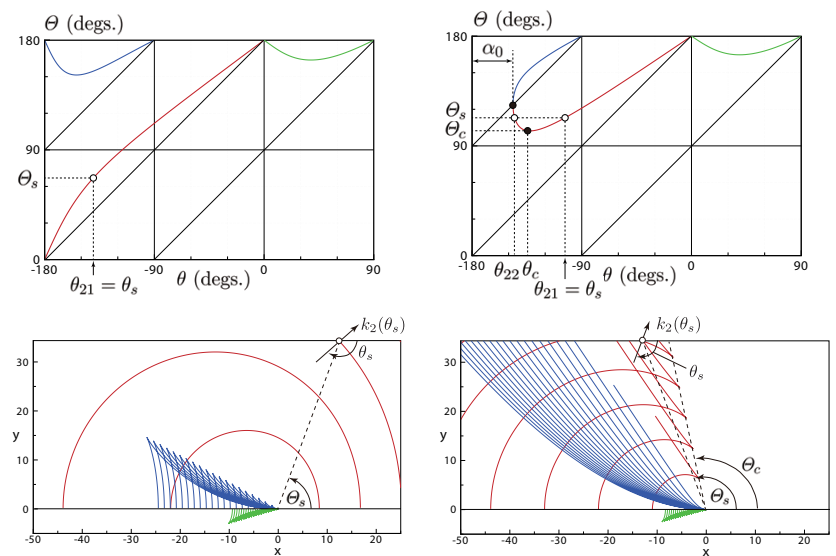

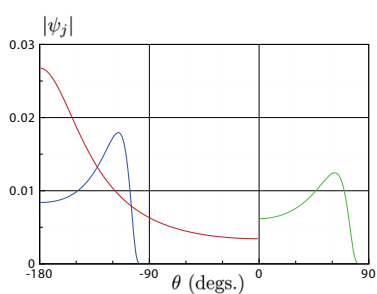

(a) for $\tau=0.2$

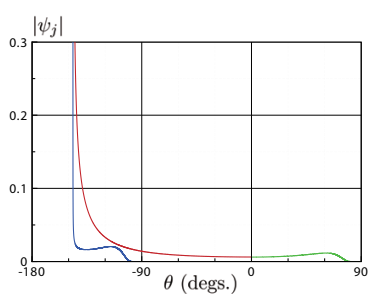

(b) for $\tau=0.3$
Fig. 10 Relation among stationary point, asymptotic wave pattern and $\psi_{j}$

Fig. 10 に停留点のグラフの例を示している。停留点の図、 漸近波紋図拉よび後述する $\left|\psi_{j}\right|$ の図中の曲線の色は $k_{1}$ 波、 $k_{2}$ 波の各波系に対応して示してある。いま停留点を求めたい検 査面 $S_{C}$ 上の $\Theta$ を $\Theta_{s}$ とする。 $\tau<1 / 4$ の場合、 $k_{2}$ は任意の $\Theta_{s}$ に対して 1 個の停留点 $\theta_{21}$ を有するので $\theta_{s}=\theta_{21}$ となる。 $\tau>1 / 4$ の場合、 $k_{2}$ 波にもカスプが存在するようになる。眓
ではカスプ角を $\Theta_{c}$ 、その停留点を $\theta_{c}$ と表している。 $\Theta_{s}<\Theta_{c}$ の場合には停留点は存在しない。 $\Theta_{c}<\Theta_{s}<\pi / 2+\alpha_{0}$ の場 合には停留点が 2 個、 $\Theta_{s}>\pi / 2+\alpha_{0}$ の場合には停留点が 1 個存在する。Fig. 10(b) の場合には、停留点は $\theta_{21}, \theta_{22}$ の 2 個 存在する。このうち円環波に相当する波長の長い方 $\left(\theta>\theta_{c}\right.$ 側) を選択したとすれば $\theta_{s}=\theta_{21}$ となる。このとき $\varphi_{j}$ および (32) は

$$
\begin{aligned}
\varphi_{j} & \sim \psi_{j}\left(k_{2}, \theta_{s}\right) e^{i k_{2} \varpi_{0}\left(\theta_{s}\right)} \\
\frac{\partial \varphi_{j}}{\partial n} & \sim i k_{2}\left(n_{1} \cos \theta_{s}+n_{2} \sin \theta_{s}\right) \psi_{j}\left(k_{2}, \theta_{s}\right) e^{i k_{2} \varpi_{0}\left(\theta_{s}\right)} \\
& =i k_{2}\left(n_{1} \cos \theta_{s}+n_{2} \sin \theta_{s}\right) \varphi_{j}
\end{aligned}
$$

となり、右辺は近似的に $\varphi_{j}$ で表せるようになる。この式は Das ら 10) や Yuan ら 11) が円環波のドップラーシフトの概念 から導出した式と完全に合致する。Fig. 10 の漸近波紋図には、 $\Theta_{s}$ と、選択した停留点 $\theta_{s}$ およびその $\theta_{s}$ で進行する素成波の 進行方向の関係とを図解している。

いま、前進速度なしの問題を考える $(\tau \rightarrow 0)$ 。このとき $k_{1}$ に関する項はなくなる。また前進速度なしの場合の波数を $k$ と すると $\tau \rightarrow 0$ の極限として $k_{2}=k$ である。また、検査面と して座標原点を中心とする円筒面を考えれば、 $n_{1}=-\cos \Theta$, $n_{2}=-\sin \Theta$ である。円環波の停留点については $\theta_{s}=\Theta-\pi$ の関係があるから、(34) は

$$
\frac{\partial \varphi_{j}}{\partial n}=i k \varphi_{j}
$$

となり、前進速度なしの場合で周知の Sommerfeld 放射条件に 州着する。こうして、前進速度ありの場合の (34) は前進速度 なしの場合の Sommerfeld 放射条件 (35) の拡張版と捉えるこ とができる。Fig. 10 には停留点と漸近波形の関係が示されて いる。船体遠方に矩形の鉛直検査面を設けた場合、検査面上 の各点 $(x, y)$ が決まれば $\Theta_{s}$ が決まる。そこでの $\theta_{s}($ これはそ の点での卓越した素成波の進行方向を示している) を求めれば (34) に代入して Sommerfeld 型の放射条件式を得ることがで きることになる。

\section{2 漸近波理論に基づく Sommerfeld 型放射条件の問題点}

さて、上記において (34) の関係を得る際に、Fig. 10(b)の ように $k_{2}$ 波系が複数の停留点 $\theta_{21}, \theta_{22}$ を持つ場合、波長の長 い方、すなわち円環波系に相当する $\theta_{21}\left(>\theta_{c}\right)$ の方を選択した。 その根拠は、 $k_{2}\left(\theta_{21}\right)<k_{2}\left(\theta_{22}\right)$ 故に $(30)$ の重み関数 $\psi_{j}$ の指 数関数部の寄与が、有限の $z$ に対して $e^{k_{2}\left(\theta_{21}\right) z}>e^{k_{2}\left(\theta_{22}\right) z}$ と なるからであると記した。同じ理由で、 $k_{2}$ 波より波数の大き い、つまり波長の短い $k_{1}$ 波は支配的でないとしている。しか し、実際にはこの前提は正しくない。

一般に (30) 中のコチン関数については、実船を想定した場 合、 $\left|H_{j}\left(k_{2}, \theta_{\ell n}\right)\right|$ に対して $\left|H_{j}\left(k_{1}, \theta_{\ell n}\right)\right|$ は 1 オーダーほど小 さい。しかし式中の $k_{1}$ 自体が特に $\theta= \pm \pi / 2$ 近傍で非常に大 きくなるため $\psi_{j}$ の值は単純に指数部のみから決まるわけでは ない。実際に $\left|H_{j}\left(k_{2}, \theta\right)\right|=1.0,\left|H_{j}\left(k_{1}, \theta\right)\right|=\left|H_{j}\left(k_{2}, \theta\right)\right| / 20$, $z=z_{0}^{\prime}=-L / 10$ の值を想定して $\theta$ に対する $\left|\psi_{j}\right|$ を計算した 
結果を Fig. 10 の最下図に示している。 $\tau=0.3$ の場合を見る と、 $\left|\psi_{j}\left(k_{2}, \theta_{22}\right)\right|>\left|\psi_{j}\left(k_{2}, \theta_{21}\right)\right|$ となっていることが分かる。 カスプ近傍では (30) 中の $\sqrt{1+4 \tau \cos \theta_{\ell n}}$ がゼロに近づく影 響で効いてくるからである $\left(\theta=-\pi+\alpha_{0}\right.$ で $\left|\psi_{j}\right|$ は無限大と なる)。 $\theta_{s}$ としては、(34) を得る際に選択した $\theta_{21}$ でなく $\theta_{22}$ を選択すべきであるということになる。 $\Theta_{s}>\pi / 2+\alpha_{0}$ の場 合、停留点は $k_{1}$ 波系から 1 個 $\left(\theta_{11}\right) 、 k_{2}$ 波系から 1 個 $\left(\theta_{21}\right)$ 得られる。各々の停留点位置での $\left|\psi_{j}\right|$ の大小比較により、寄与 度の高い停留点を選択して (34)の $\theta_{s}$ として用いなくてはなら ないが、それは $\left|H_{j}\left(k_{1}, \theta_{11}\right)\right|,\left|H_{j}\left(k_{2}, \theta_{21}\right)\right|$ やz $z$ 值で異なっ てくる。加えて、1 次の漸近展開をべースとした停留位相法自 体、カスプ近傍では精度が悪化するので Fig. 10 の停留位相図 を用いて寄与度の高い停留点 $\theta_{s}$ を選択することそのものが不 合理となってしまう (カスプ近傍では 2 次の漸近展開が必要)。

こうして、最初から円環波のみを寄与度の高い停留点として 選択し、円環波のドップラーシフトの概念から (34) を得た Das ら 10) やYuan ら 11) の方法は、漸近波理論から考えると不合 理さを含む方法であるという結論に至るのである $(\tau<0.25$ で あれば問題ないので完全に不合理とは言う訳ではない)。もう 一つ彼らの方法には問題がある。Fig. 10(b) 最上図から容易に 分かるように、 $S_{C}$ 上の点が、 $\Theta_{s}<\Theta_{c}$ のようにカスプ角より 小さくなると停留点が存在しなくなる。従って (34) の右辺に はゼロを代入することになる。 $\Theta_{s}>\Theta_{c}$ では停留点が存在す るので右辺は有限值であるから、 $S_{C}$ 上に課す境界条件にジャ ンプが起こる。Fig. 10(b) の中段図において、 $S_{C}$ 上の点 (白 丸）を上流側に移動させて行ったとき、カスプ角外に出た瞬間 に法線流速としてゼロを代入することになり、当然ながら検査 面 $S_{C}$ 近傍の流場の連続性の観点から問題がある。

\section{3 より合理的な条件}

Das ら 10) や Yuan ら 11) の方法は、漸近波理論の観点から は不合理な点を含みながらも数值解としてはある程度の成果を 得ている。それをベースにした改善法として、(1)に示した波 核関数を用いて (34) 右辺の $\varphi_{j}$ に掛かる複素係数を厳密に求 る方法が考えられよう。つまり、 $S_{C}$ 上の任意点を $\mathrm{P}$ として

$$
\frac{\partial G_{W}\left(\mathrm{P}, \mathrm{Q}_{0}\right)}{\partial n_{\mathrm{P}}}=\alpha(\mathrm{P}) G_{W}\left(\mathrm{P}, \mathrm{Q}_{0}\right)
$$

から複素係数 $\alpha(\mathrm{P})$ を求める。これを $(34)$ に用いて

$$
\frac{\partial \varphi_{j}(\mathrm{P})}{\partial n}=\alpha(\mathrm{P}) \varphi_{j}(\mathrm{P})
$$

なる境界条件とする。 2 章に記した単一特異点まわりの境界值 問題における積分方程式に組み込む場合には、 $\varphi_{j} \rightarrow \phi$ と書き 換えて使用すればよい。 2.2 節のパネルシフト法と一緒に使用 する場合、(5) に対応する式は境界面に $S_{C}$ を加えて

$$
\phi(\mathrm{P})=G_{0}\left(\mathrm{P}, \mathrm{Q}_{0}\right)-\iint_{S_{F}+S_{C}} \sigma(\mathrm{Q}) \tilde{G}(\mathrm{P}, \mathrm{Q}) d S
$$

ただし、

$$
\tilde{G}(\mathrm{P}, \mathrm{Q})= \begin{cases}G(\mathrm{P}, \mathrm{Q}) & \mathrm{Q} \in S_{F} \\ G_{0}(\mathrm{P}, \mathrm{Q}) & \mathrm{Q} \in S_{C}\end{cases}
$$

となる。同様に、吹き出し分布に関する積分方程式 (7) に対応 する式は

$\iint_{S_{F}+S_{C}} \mathcal{L}[\tilde{G}(\mathrm{P}, \mathrm{Q})] \sigma(\mathrm{Q}) d S=\mathcal{L}\left[G_{0}\left(\mathrm{P}, \mathrm{Q}_{0}\right)\right]_{\mu=0} \quad$ for $\mathrm{P} \in S_{F}$

となる。これに加えて $\mathrm{P} \in S_{C}$ の場合、(38)、(37) より新たに

$$
\begin{aligned}
& \iint_{S_{F}+S_{C}} \sigma(\mathrm{Q})\left\{\frac{\partial \tilde{G}(\mathrm{P}, \mathrm{Q})}{\partial n_{\mathrm{P}}}-\alpha(\mathrm{P}) \tilde{G}(\mathrm{P}, \mathrm{Q})\right\} d S \\
& =\frac{\partial G_{0}\left(\mathrm{P}, \mathrm{Q}_{0}\right)}{\partial n_{\mathrm{P}}}-\alpha(\mathrm{P}) G_{0}\left(\mathrm{P}, \mathrm{Q}_{0}\right) \quad \text { for } \mathrm{P} \in S_{C}
\end{aligned}
$$

の方程式が得られ、(40), (41) を一定要素の仮定で離散化して 解くことにより吹き出し分布を求めることができる。

この方法によれば漸近波理論を用いた場合のような停留点 の選択は不要であるし、カスプ上での計算も正確に行える。な お、(37) は、もともと漸近波理論に基づいて得られた形の条 件式であるから、 $S_{C}$ は十分遠方に設定する必要がある。実船 の境界值問題のように船体近傍で二重模型流場を考慮する場合 であっても、 $S_{C}$ を十分に遠方に取れば、そこでの自由表面条 件は (3) の Neumann-Kelvin 型に漸近するので本方法の適用 に問題はないであろう。

\section{4 条件式 (37) の解釈について}

(37) は、Bai ら 19) が前進速度なしの問題において Finiteelement variational method や Fundamental-singularity distribution method を定式化する際に、物体近くの近場と遠方 場とを結びつける接合条件として使用したものと類似の形と なっている。また、近年では吉田ら 20$)$ も同様の条件を用いて おり、そういう意味で (37) は新規の条件式であるわけではな い。前進速度がある 3 次元問題については、岩下ら ${ }^{21)}$ が結合 境界積分方程式法と称して実際に計算した例があるので、そこ で使用された接合条件と (37) との関係を考察しておく。

結合境界積分方程式法 (ハイブリッド法と呼ぶこともある。 以降、本論文中では簡単のために結合法と記す) では、物体近 傍 (本論文の場合単一特異点近傍) の内部領域と遠方の外部領 域とに分けて考え、各々の領域で境界積分方程式を立て、内部 領域と外部領域を分ける検査面上 (いまの場合 $S_{C}$ 上) で両方 の解を接合させる。

内部領域の速度ポテンシャルの表示式および吹き出し分布 に関する積分方程式は (38) (41) と同じである。外部領域で の速度ポテンシャルを $\phi^{*}(\mathrm{P})$ と記し、それを $S_{C}$ 上の吹き出 し分布 $\sigma^{*}(\mathrm{Q})$ で表すと、グリーン関数法の間接法を適用して (18) と同様に

$$
\begin{aligned}
\phi^{*}(\mathrm{P})= & -\iint_{S_{C}} \sigma^{*}(\mathrm{Q}) G_{W}(\mathrm{P}, \mathrm{Q}) d S \\
& +\frac{1}{K_{0}} \oint_{C} \sigma^{*}(\mathrm{Q}) G_{W}(\mathrm{P}, \mathrm{Q}) n_{x^{\prime}}^{*} d y^{\prime}
\end{aligned}
$$

となる。ここで、 $S_{C}$ から外部領域へ向かう法線を $n^{*}$ として $n_{x^{\prime}}^{*}$ はその $x$ 成分を表している。また $C$ は $S_{C}$ と $z=0$ 面と 
の交線である。 $\mathrm{P} \in S_{C}$ の場合の積分方程式として

$$
\begin{aligned}
\frac{\partial \phi^{*}(\mathrm{P})}{\partial n^{*}}= & \frac{\sigma^{*}(\mathrm{P})}{2}-\iint_{S_{C}} \sigma^{*}(\mathrm{Q}) \frac{\partial G_{W}(\mathrm{P}, \mathrm{Q})}{\partial n_{\mathrm{P}}^{*}} d S \\
& +\frac{1}{K_{0}} \oint_{C} \sigma^{*}(\mathrm{Q}) \frac{\partial G_{W}(\mathrm{P}, \mathrm{Q})}{\partial n_{\mathrm{P}}^{*}} n_{x^{\prime}}^{*} d y^{\prime} \quad\left(\mathrm{P} \in S_{C}\right)
\end{aligned}
$$

を得る。 $S_{C}$ を $N_{C}$ 個のパネルに分割して一定要素で離散化 し、各パネルの速度ポテンシャル、吹き出し分布を $\phi_{i}^{*}, \sigma_{i}^{*}$ と 記すことにすると、(42)，(43) は下記のようにマトリックス表 記することができる。

$$
\begin{aligned}
{\left[\phi_{i}^{*}\right]^{N_{C}}=} & {\left[\mathcal{G}_{i j}\right]_{N_{C}}^{N_{C}}\left[\sigma_{j}^{*}\right]^{N_{C}} } \\
{\left[\frac{\partial \phi_{i}^{*}}{\partial n^{*}}\right]^{N_{C}} } & =\left[\frac{\partial \mathcal{G}_{i j}}{\partial n^{*}}\right]_{N_{C}}^{N_{C}}\left[\sigma_{j}^{*}\right]^{N_{C}} \\
& =\left[\frac{\partial \mathcal{G}_{i j}}{\partial n^{*}}\right]_{N_{C}}^{N_{C}}\left[\mathcal{G}_{i j}\right]^{-1 N_{C}}\left[\phi_{j}^{*}\right]^{N_{C}} \\
& \equiv\left[B_{i j}\right]_{N_{C}}^{N_{C}}\left[\phi_{j}^{*}\right]^{N_{C}}
\end{aligned}
$$

ただし、

$$
\left.\begin{array}{l}
\mathcal{G}_{i j} \\
\frac{\partial \mathcal{G}_{i j}}{\partial n^{*}}
\end{array}\right\} \equiv \iint_{\Delta S_{j}}\left\{\begin{array}{l}
G_{W}\left(\mathrm{P}_{i}, \mathrm{Q}\right) \\
\frac{\partial G_{W}\left(\mathrm{P}_{i}, \mathrm{Q}\right)}{\partial n_{\mathrm{P}}^{*}}
\end{array}\right\} d S
$$

$\mathrm{P}_{i}$ は $i$ 番目のパネルの代表点の座標、 $\Delta S_{j}$ は $j$ 番目のパネル 内での積分を意味している。 $\Delta S_{j}$ が水面に接している場合に は、(47) 右辺に (42), (43) の線積分項を含めて計算する約束 とする。また、 $\mathrm{P}=\mathrm{Q}$ の場合に現れる $\partial G_{W} / \partial n_{\mathrm{P}}^{*}$ の特異性に 起因した $\sigma(\mathrm{P}) / 2$ の項は $(47)$ 右辺に含めて表している。こう して (46)は

$$
\frac{\partial \phi_{i}^{*}}{\partial n^{*}}=\sum_{j=1}^{N_{C}} B_{i j} \phi_{j}^{*} \quad\left(i=1 \sim N_{C}\right)
$$

のように表すことができる。

一方、内部領域において $\mathrm{P} \in S_{C}$ の場合の積分方程式は (38) より

$$
\begin{aligned}
\frac{\partial \phi(\mathrm{P})}{\partial n}= & \frac{\partial G_{0}\left(\mathrm{P}, \mathrm{Q}_{0}\right)}{\partial n_{\mathrm{P}}} \\
& +\frac{\sigma(\mathrm{P})}{2}-\iint_{S_{F}+S_{C}} \sigma(\mathrm{Q}) \frac{\partial \tilde{G}(\mathrm{P}, \mathrm{Q})}{\partial n_{\mathrm{P}}} d S
\end{aligned}
$$

となる。 $S_{C}$ 上と同様に、自由表面 $S_{F}$ を $N_{F}$ 個のパネルに 分割し、一定要素の仮定で離散化した各パネルの速度ポテン シャル、吹き出し分布を $\phi_{i}, \sigma_{i}$ と表すと (38) および (49) は $i=N_{F}+1 \sim N_{F}+N_{C}$ に対して次式のように表すことがで きる。

$$
\begin{aligned}
& \phi_{i}=G_{0}\left(\mathrm{P}_{i}, \mathrm{Q}_{0}\right)-\sum_{j=1}^{N_{F}+N_{C}} \tilde{\mathcal{G}}_{i j} \sigma_{j} \\
& \frac{\partial \phi_{i}}{\partial n}=\frac{\partial G_{0}\left(\mathrm{P}_{i}, \mathrm{Q}_{0}\right)}{\partial n_{\mathrm{P}}}-\sum_{j=1}^{N_{F}+N_{C}} \frac{\partial \tilde{\mathcal{G}}_{i j}}{\partial n} \sigma_{j}
\end{aligned}
$$

ここで $\tilde{\mathcal{G}}_{i j}, \partial \tilde{\mathcal{G}}_{i j} / \partial n$ は (47) と同様に

$$
\left.\begin{array}{l}
\tilde{\mathcal{G}}_{i j} \\
\frac{\partial \tilde{\mathcal{G}}_{i j}}{\partial n}
\end{array}\right\} \equiv \iint_{\Delta S_{j}}\left\{\begin{array}{l}
\tilde{G}\left(\mathrm{P}_{i}, \mathrm{Q}\right) \\
\frac{\partial \tilde{G}\left(\mathrm{P}_{i}, \mathrm{Q}\right)}{\partial n_{\mathrm{P}}}
\end{array}\right\} d S
$$

で定義している。(49)の $\partial \tilde{G} / \partial n_{\mathrm{P}}$ の特異性に起因した $\sigma(\mathrm{P}) / 2$ の項は (52) 右辺に含めて表している。

内部領域と外部領域との境界面 $S_{C}$ 上で流場が連続である 条件 (接合条件) として

$$
\left.\begin{array}{l}
\phi(\mathrm{P})=\phi^{*}(\mathrm{P}) \\
\frac{\partial \phi(\mathrm{P})}{\partial n}=-\frac{\partial \phi^{*}(\mathrm{P})}{\partial n^{*}}
\end{array}\right\} \quad\left(\mathrm{P} \in S_{C}\right)
$$

あるいは離散表記で

$$
\left.\begin{array}{l}
\phi_{i}=\phi_{i-N_{F}}^{*} \\
\frac{\partial \phi_{i}}{\partial n}=-\frac{\partial \phi_{i-N_{F}}^{*}}{\partial n^{*}}
\end{array}\right\} \quad\left(i=N_{F}+1 \sim N_{F}+N_{C}\right)
$$

が満足されなくてはならない。

(51)に (48), (50)，(54) を用いると最終的に次の離散化され た方程式を得る。

$$
\begin{aligned}
\sum_{j=1}^{N_{F}+N_{C}}\left\{\frac{\partial \tilde{\mathcal{G}}_{i j}}{\partial n}+\sum_{k=1}^{N_{C}} B_{i-N_{F}, k} \tilde{\mathcal{G}}_{k+N_{F}, j}\right\} \sigma_{j} \\
=\frac{\partial G_{0}\left(\mathrm{P}_{i}, \mathrm{Q}_{0}\right)}{\partial n_{\mathrm{P}}}+\sum_{k=1}^{N_{C}} B_{i-N_{F}, k} G_{0}\left(\mathrm{P}_{k+N_{F}}, \mathrm{Q}_{0}\right) \\
\left(i=N_{F}+1 \sim N_{F}+N_{C}\right)
\end{aligned}
$$

これと $\mathrm{P} \in S_{F}$ の場合の積分方程式 (40) を一定要素の仮定で 離散化した方程式とを連立して $\sigma_{j}$ について解くことにより解 を求める。以上が結合法である。

上記のように外部領域に境界積分方程式法を適用するので はなく、単に $\mathrm{Q}_{0}$ に置かれた強さ $\sigma^{*}\left(\mathrm{Q}_{0}\right)$ の単一特異点により 外部領域の速度ポテンシャル $\phi^{*}(\mathrm{P})$ が近似的に表せるとして 定式化を行うことができる (本論文で扱っている単一特異点周 りの流場を解く例題では、近似ではなく厳密に成立する)。そ の結果は、形式的には (45), (46) において

$$
\begin{aligned}
& {\left[\frac{\partial \phi_{i}^{*}}{\partial n^{*}}\right]^{N_{C}} \longrightarrow \frac{\partial \phi^{*}(\mathrm{P})}{\partial n^{*}}=-\frac{\partial \phi(\mathrm{P})}{\partial n}(\because \text { eq. }(53))} \\
& {\left[\frac{\partial \mathcal{G}_{i j}}{\partial n^{*}}\right]_{N_{C}}^{N_{C}} \longrightarrow \frac{\partial G_{W}\left(\mathrm{P}, \mathrm{Q}_{0}\right)}{\partial n_{\mathrm{P}}^{*}}=-\frac{\partial G_{W}\left(\mathrm{P}, \mathrm{Q}_{0}\right)}{\partial n_{\mathrm{P}}}} \\
& {\left[\mathcal{G}_{i j}\right]^{-1 N_{C}} \longrightarrow 1 / G_{W}\left(\mathrm{P}, \mathrm{Q}_{0}\right)} \\
& {\left[\phi_{j}^{*}\right]^{N_{C}} \longrightarrow \phi^{*}(\mathrm{P})=\phi(\mathrm{P}) \quad(\because \text { eq. }(53))} \\
& {\left[B_{i j}\right]_{N_{C}}^{N_{C}} \longrightarrow \frac{\partial G_{W}\left(\mathrm{P}, \mathrm{Q}_{0}\right)}{\partial n_{\mathrm{P}}^{*}}=\frac{-\frac{\partial G_{W}\left(\mathrm{P}, \mathrm{Q}_{0}\right)}{\partial n_{\mathrm{P}}}}{G_{W}\left(\mathrm{P}, \mathrm{Q}_{0}\right)}=-\alpha(\mathrm{P}) \quad(\because \text { eq. }(36))}
\end{aligned}
$$

と置き換えたものと同じになる。つまり (37) で $\varphi_{j} \rightarrow \phi$ と読 み替えたものと同じ条件式が得られることになる。この置き換 えの際に線積分項を無視しているが、この影響に関しては次節 の計算例で述べることにする。ちなみに、この場合の (55)に 対応する式は

$$
\begin{gathered}
\sum_{j=1}^{N_{F}+N_{C}}\left\{\frac{\partial \tilde{\mathcal{G}}_{i j}}{\partial n}-\alpha_{i} \tilde{\mathcal{G}}_{i j}\right\} \sigma_{j}=\frac{\partial G_{0}\left(\mathrm{P}_{i}, \mathrm{Q}_{0}\right)}{\partial n_{\mathrm{P}}}-\alpha_{i} G_{0}\left(\mathrm{P}_{i}, \mathrm{Q}_{0}\right) \\
\left(i=N_{F}+1 \sim N_{F}+N_{C}\right)
\end{gathered}
$$


となる。ここで、 $\alpha_{i}$ は $i$ 番目パネル代表点 $\mathrm{P}_{i}$ での $\alpha$ の值 $\alpha\left(\mathrm{P}_{i}\right)$ を表している。

以上から、 $S_{C}$ 上での境界条件 (37) は、結合法の枠組みに おける接合条件と類似の条件式であると解釈することができ る。係数 $\alpha(\mathrm{P})$ を (36) から得る場合、 $\alpha(\mathrm{P})$ には $G_{W}$ を通し て、単に進行波の情報のみでなく局所波などの影響も含まれて おり、そういう意味からも Sommerfeld 放射条件と言うよりは 内部解と外部解との接合条件と理解した方が適切であろう。以 降、本論文では他の計算法と区別するため、 $S_{C}$ 上で条件 $(37)$ を課す方法を簡易結合法と呼ぶことにする。

上記の定式化では外部領域にグリーン関数法の間接法を使 用しているが、直接法によっても同様の定式化が行える。岩下 ら 22)によると、直接法で定式化した方が計算精度が良いとさ れている。次節の計算例で示す結合法では、直接法を用いた計 算例を示すことから、ここで直接法に基づく定式化も示してお く。まず、直接法では (43) に対応する式は次のようになる。

$$
\begin{aligned}
\frac{\phi^{*}(\mathrm{P})}{2} & -\iint_{S_{C}} \frac{\partial G_{W}(\mathrm{P}, \mathrm{Q})}{\partial n_{\mathrm{Q}}^{*}} \phi^{*}(\mathrm{Q}) d S \\
& +\frac{1}{K_{0}} \oint_{C}\left\{\frac{\partial G_{W}(\mathrm{P}, \mathrm{Q})}{\partial x^{\prime}}+2 i K_{0} \tau G_{W}(\mathrm{P}, \mathrm{Q})\right\} \phi^{*}(\mathrm{Q}) d y^{\prime} \\
= & -\iint_{S_{C}} \frac{\partial \phi^{*}(\mathrm{Q})}{\partial n_{\mathrm{Q}}^{*}} G_{W}(\mathrm{P}, \mathrm{Q}) d S \\
& +\frac{1}{K_{0}} \oint_{C} \frac{\partial \phi^{*}(\mathrm{Q})}{\partial x^{\prime}} G_{W}(\mathrm{P}, \mathrm{Q}) d y^{\prime}
\end{aligned}
$$

$S_{C}$ として Fig.11のような直方体を考えれば、線積分項とし ては上流断面と下流断面の $z=0$ の線分に沿った積分のみが 寄与し、各々において

$$
\left.\frac{\partial}{\partial x^{\prime}}= \pm \frac{\partial}{\partial n_{\mathrm{Q}}^{*}} \quad \text { (上流面、下流面に応じて複号合順 }\right)
$$

の関係が成立する。よって、 $\partial \phi / \partial x^{\prime}$ の計算を、未知関数であ る $\phi$ を用いて表す (たとえば差分近似表示) などの必要はなく、 線積分項の計算は簡単に処理できる。(57) を一定要素の仮定 で離散化すると、(44)〜(46) に対応するマトリックス表示とし て次式を得る。

$$
\left[\frac{\partial \mathcal{G}_{i j}^{\prime}}{\partial n^{*}}\right]_{N_{C}}^{N_{C}}\left[\phi_{i}^{*}\right]^{N_{C}}=\left[\mathcal{G}_{i j}^{\prime}\right]_{N_{C}}^{N_{C}}\left[\frac{\partial \phi_{i}^{*}}{\partial n^{*}}\right]^{N_{C}}
$$

ただし、

$$
\left.\begin{array}{l}
\mathcal{G}_{i j}^{\prime} \\
\frac{\partial \mathcal{G}_{i j}^{\prime}}{\partial n^{*}}
\end{array}\right\} \equiv \iint_{\Delta S_{j}}\left\{\begin{array}{l}
G_{W}\left(\mathrm{P}_{i}, \mathrm{Q}\right) \\
\frac{\partial G_{W}\left(\mathrm{P}_{i}, \mathrm{Q}\right)}{\partial n_{\mathrm{Q}}^{*}}
\end{array}\right\} d S
$$

(57) 中の線積分項や特異性に関する項 $\phi^{*}(\mathrm{P}) / 2$ は (60) 右辺 の項に含めて表記している。(59)より、(45), (46) に対応する 関係式として

$$
\begin{aligned}
{\left[\frac{\partial \phi_{i}^{*}}{\partial n^{*}}\right]^{N_{C}} } & =\left[\mathcal{G}_{i j}^{\prime}\right]_{N_{C}}^{-1 N_{C}}\left[\frac{\partial \mathcal{G}_{i j}^{\prime}}{\partial n^{*}}\right]_{N_{C}}^{N_{C}}\left[\phi_{j}^{*}\right]^{N_{C}} \\
& \equiv\left[B_{i j}^{\prime}\right]_{N_{C}}^{N_{C}}\left[\phi_{j}^{*}\right]^{N_{C}}
\end{aligned}
$$

を得る。こうして (48) に対応する式として

$$
\frac{\partial \phi_{i}^{*}}{\partial n^{*}}=\sum_{j=1}^{N_{C}} B_{i j}^{\prime} \phi_{j}^{*} \quad\left(i=1 \sim N_{C}\right)
$$

を得るが、これは単に(48)において $B$ を $B^{\prime}$ に書き換えただ けのものになっている。この後の定式化は、前述の間接法に基 づく場合と全く一緒であり、最終的に得られる方程式も (55) において $B \rightarrow B^{\prime}$ と書き換えたものになる。

\section{5 接合条件と数値解}

前節において結合法の定式化を示した。また、外部解を近 似的に扱った場合の接合条件が (37) となることも示した。そ こで、これらの定式化に則して得られる数值解にどのような相 違があるかを調べてみることにする。

まず、数值計算に際して、Fig.11 に示す 3 種類の計算格子 を準備する。内部領域と外部領域を分ける検査面 $S_{C}$ は、自由 表面を取り囲む鉛直検査面としている。3.3 節に示したように、 自由表面の吹き出し分布面を $z$ 軸方向にシフトさせることに より、計算される波角が改善されることが既に分かっている ので、いわゆる $z$-shift はどの計算格子にも適用している。こ の操作により、前節までの定式化における吹き出し分布面 $S_{F}$ は、静水面 $z=0$ より上方に $\Delta z$ だけシフトした面となる点 に注意されたい。 $S_{F}$ のパネル面内積分はこの面上で行う。な お、図中静水面 $z=0$ 位置に描かれた点線は $z$-shift 前の $S_{F}$ 上の計算格子を示しており、 $x$-shift はこの面上で行う。

Grid-1 は結合法に適用する計算格子となっている。図中の プロット点が境界条件を課す選点を示している。結合法では、 $S_{C}$ 上での接合条件 $(53)$ を介して無限遠条件が満足されるた め、 $S_{F}$ 上での $x$-shift など数值的に無限遠条件を満足させる ための条件は不要であるはずであるから、 $x$-shift は行ってい ない。

Grid-2 は、 $S_{F}$ 上で通常のパネルシフト法 (選点の $x$-shift) を用いる際の計算格子となっている。 $S_{F}$ 上で $x$-shift を適用し ており、 $S_{C}$ と $S_{F}$ の間には、最上流列に 1 パネル分の隙間が 設けてある。 $S_{F}$ 上の選点では全域で自由表面条件のみを課す。

Grid-3 は、 $S_{F}$ 上で $x$-shift を行うと共に最上流列で選点を 重ねて二重条件を課すことができるようになっている。二重条 件としてはSclavounos \& Nakos の条件 (16) を適用した場合 や、3.2 節 (c) の条件 (Figs.7(c), 8(c)) を適用した場合を検討 する。後者の二重条件により、通常のパネルシフト法と同等の 結果が得られることが 3.2 節において示されていることから、 $S_{C}$ を付加した場合においても同様の結果になるのかを確認す る目的からである。

$S_{F}$ 上の格子分割数は、 $x$ 軸方向に 80 分割 (等間隔)、 $y$ 軸 方向に 32 分割 (不等間隔で $y$ が大きくなるほど粗となる) と している。 $x$ 軸方向に対する $y$ 軸方向の計算領域の比率は 3.1 , 3.2 節の計算と同様に 0.6 としている。 $S_{C}$ の深さについて は、 $F_{n}, K_{e} L$ の計算条件下で、特異点が造波する $k_{1}$ 波、 $k_{2}$ 波の中で最も波長の長い $k_{2}(\theta=0)(x$ 軸後方へ伝搬する波。 


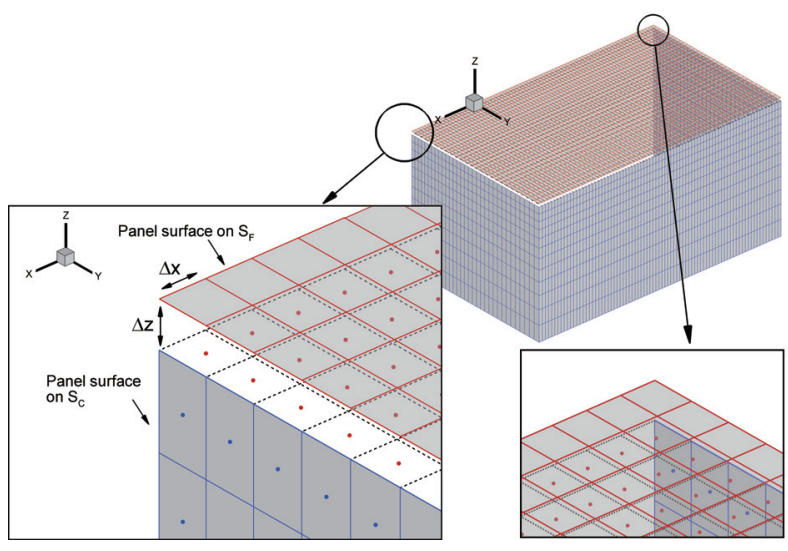

(a) Grid-1

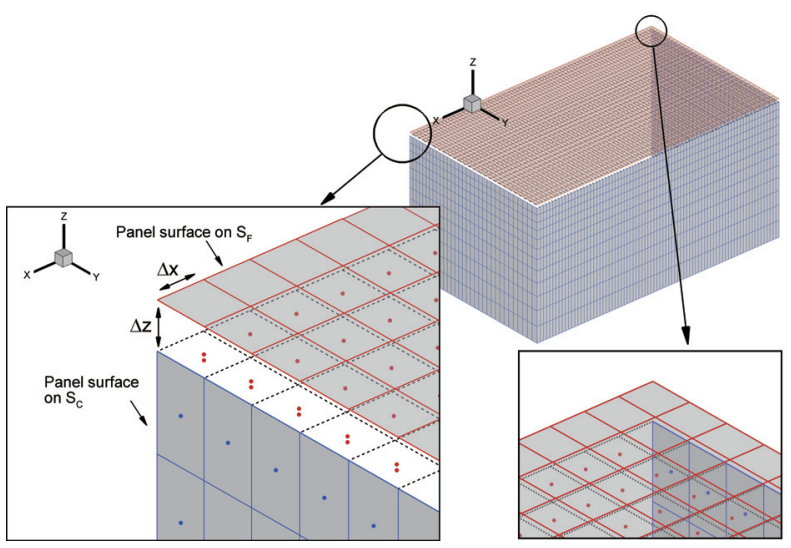

(c) Grid-3

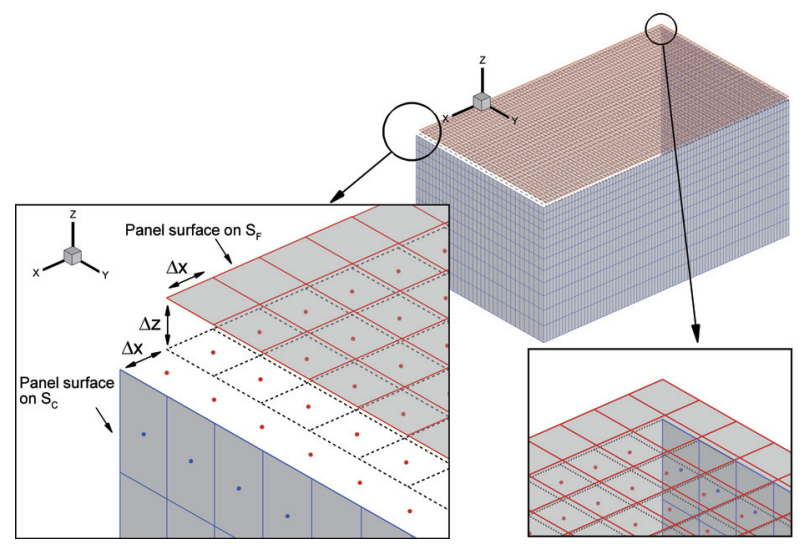

(b) Grid-2

\begin{tabular}{|c|c|c|c|}
\hline Mesh type & $x$-shift & $z$-shift & $\begin{array}{c}\text { Double } \\
\text { collocation } \\
\text { points }\end{array}$ \\
\hline (a) Grid-1 & $\times$ & $\bigcirc$ & $\times$ \\
(b) Grid-2 & $\bigcirc$ & $\bigcirc$ & $\times$ \\
(c) Grid-3 & $\bigcirc$ & $\bigcirc$ & $\bigcirc$ \\
\hline
\end{tabular}

Fig. 11 Perspective views of three different computation grids

Fig. 10 の停留点の図参照) から決定している。 $\tau=F_{n} \sqrt{K_{e} L}$, $K_{0}=1 /\left(F_{n}^{2} L\right)$ であるから

$$
k_{2}(0)=\frac{K_{0}}{2}(1+2 \tau-\sqrt{1+4 \tau})
$$

となるので、 $S_{C}$ の深さはこの $k_{2}$ から算出される波長の半分 としている。この深さで波動は十分に減衰するので $S_{C}$ の底面 を格子分割する必要はない。計算格子は水深が浅くなるほど密 になるように 12 分割しており、 $S_{C}$ での $x$ 軸方向、 $y$ 軸向の グリッド点は $S_{F}$ 端部のそれらと重なるようにしている。

Fig.12に $F_{n}=0.2, K_{e} L=3.0, \tau=0.346$ の場合の結果を 示している。図中に示す複数の計算で使用した計算格子や $S_{F}$ 最上流列での二重条件、 $S_{C}$ 上での接合条件を図中左下の表に まとめてある。 CM(Combined Method) は結合法における条 件を課したもので、 $\mathrm{P} \in S_{C}$ での方程式として (55)を解いてい る。SCM(Simplified Combined Method) は前節で定義した 簡易結合法であり、 $S_{C}$ 上で $(37)$ の条件 $(\alpha(\mathrm{P})$ は $(36)$ より計 算) を与え、 $\mathrm{P} \in S_{C}$ での方程式としては (56) を解いている。

図中 (a) は波核関数 $G_{W}$ を計算した結果であり、ここでは 厳密解と見なしている。(b) は、計算格子として Grid-1 を用 い、結合法の定式化に則して計算された結果である。 $S_{F}$ 上の ポテンシャル分布は全体的には捉えられているものの、細かい
波が混在しており決して精度の高い結果とは言えない。パネル シフトなど数值的処理に頼らずに、無限遠条件を厳密に満足す る外部解と内部解とを $S_{C}$ 上で接合することで無限遠条件を満 足する、数学的には問題のない方法であるが、数值的には精 度の高い解を得ることが難しいことが分かる。なお、岩下ら 21)22) の計算では、内部領域をかなり船体近傍 (本論文の場合 特異点近傍)に設定しており、その結果精度を維持した結果を 得ている。今回、計算精度が不十分であるのは、計算領域の広 さや計算格子数との関連等が主要因と思われるが、明確な原因 は不明である。

(c) は、パネルシフト法と結合法とを組み合わせた方法であ る。無限遠条件の観点からは両方法のブレント法と言ってよ い。 $S_{F}$ 上で $x$-shift を行うため、Grid-2 を用いている。プロ グラムコード上は、単に (b) の計算コードにおいて Grid-1 を Grid-2 に入れ替えるのみで得られる結果である。その結果は、 (b)において見られた細かい波がなくなるとともに、パネルシ フト法単独で問題となっていた計算領域の幅方向端部からの反 射波のような現象 (Fig.5 参照) がなくなり、結果的に (a) の厳 密解と極めて良い合致を示す。( $\left.c^{\prime}\right)$ は $S_{C}$ 上での接合条件とし て (37) を用い、 $\mathrm{P} \in S_{C}$ での方程式として (56) を解いた結果 である。(c) とほとんど同じ結果を得ることができる。前節に 

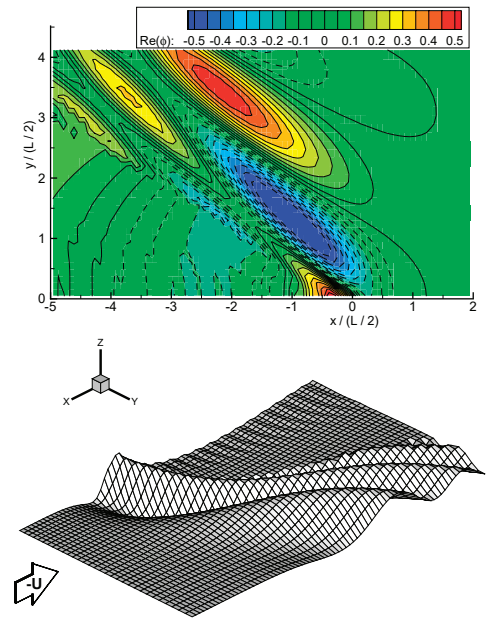

(a) Wave source (exact)

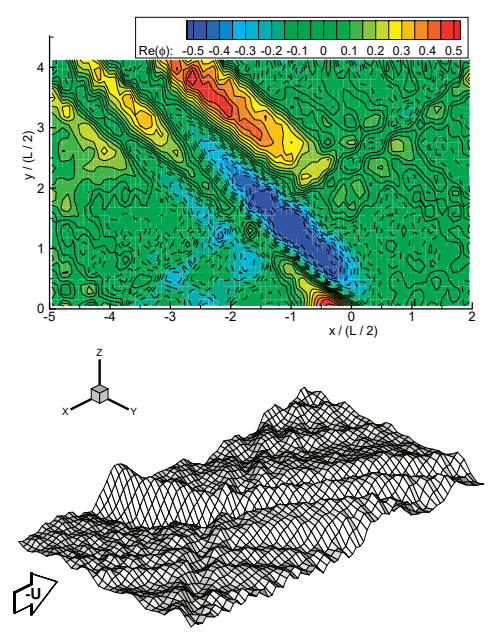

(b) CM with Grid-1

Condition table

\begin{tabular}{|c|c|l|c|}
\hline & \multirow{2}{*}{ Grid } & $\begin{array}{l}\text { Dual } \\
\text { conditions at } \\
\text { fore end } \\
\text { points on } S_{F}\end{array}$ & $\begin{array}{l}\text { Condition } \\
\text { on } S_{C}\end{array}$ \\
\hline \hline (b) & Grid-1 & - & CM \\
\hline (c) & \multirow{2}{*}{ Grid-2 } & - & CM \\
\cline { 1 - 2 } (c') & \multirow{2}{*}{ Grid-3 } & $\begin{array}{l}\text { eq. }(16) \\
\left(\zeta=0, \phi_{z}=0\right)\end{array}$ & SCM \\
\cline { 1 - 1 } (d) & SCM \\
\hline (e) & \multirow{2}{*}{ Grid-3 } & $\begin{array}{l}S_{F} \text { condi., } \\
\phi_{z}=0\end{array}$ & CM \\
\cline { 1 - 1 } (e') & & SCM \\
\hline
\end{tabular}

CM : Combined method

SCM: Simplified combined method

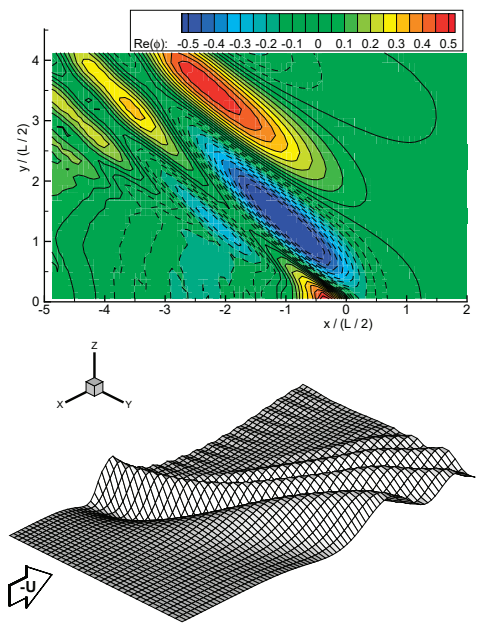

(c) CM with Grid-2
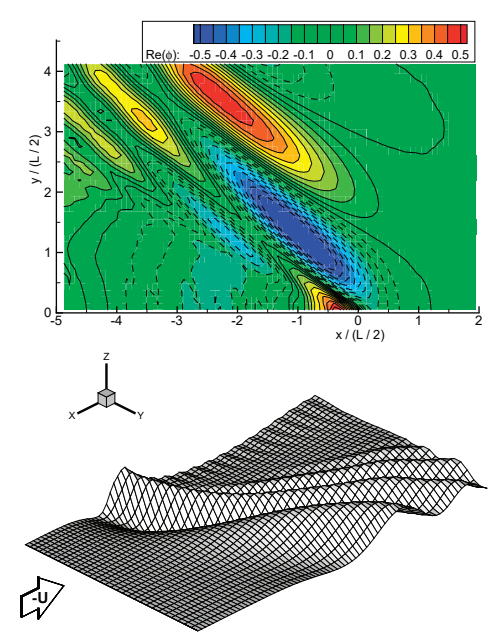

(d) CM with Grid-3

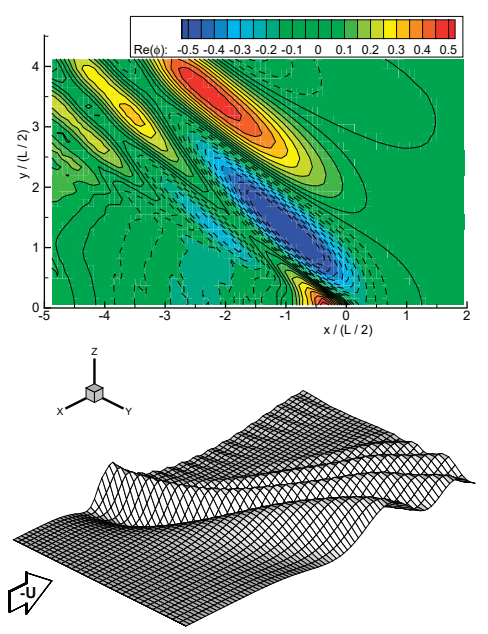

(e) CM with Grid-3

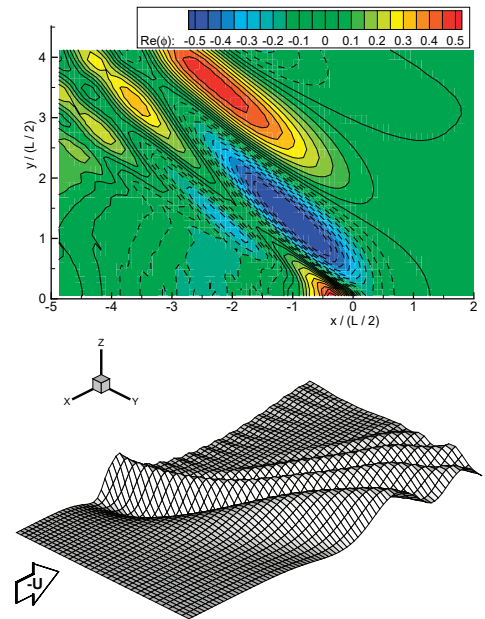

(c') SCM with Grid-2
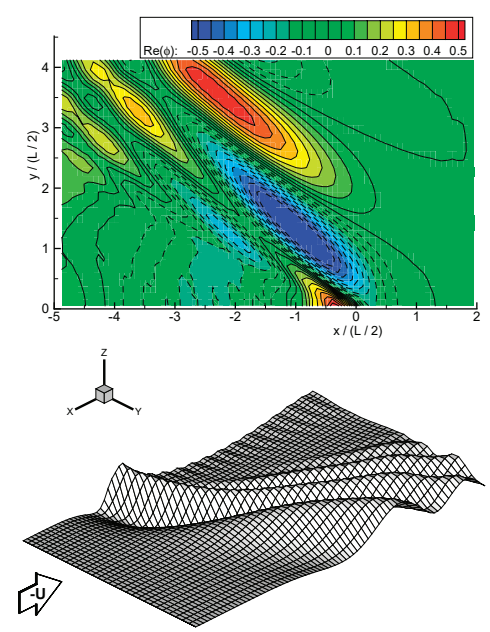

(d') SCM with Grid-3

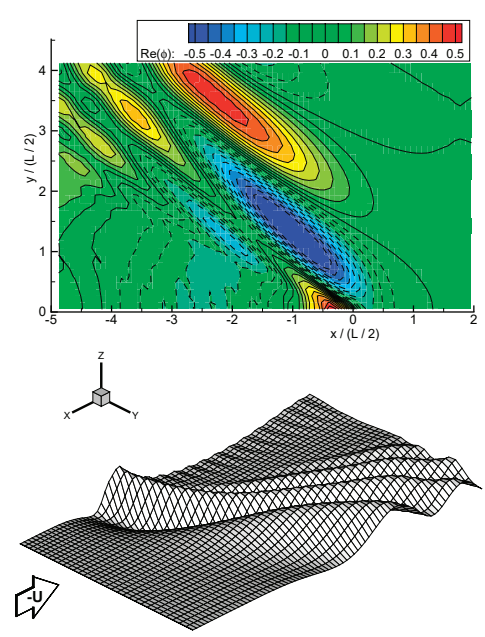

(e') SCM with Grid-3

Fig. 12 Distribution of $\operatorname{Re}[\phi]$ by blend methods of panel-shift method and CM/SCM for $F_{n}=0.2, K_{e} L=3, \tau=0.346$ 

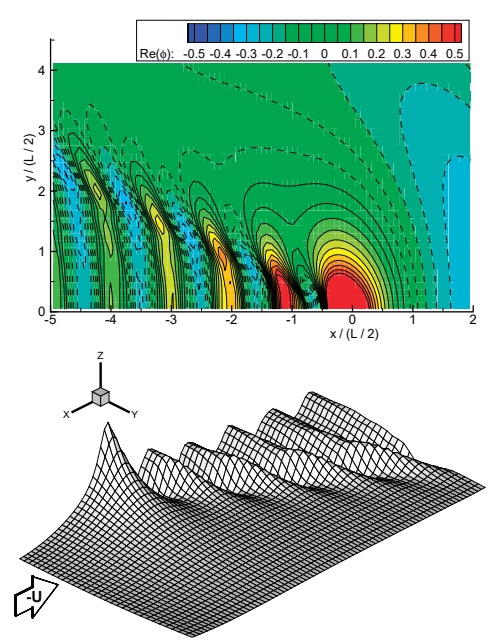

(a) Wave source (exact)
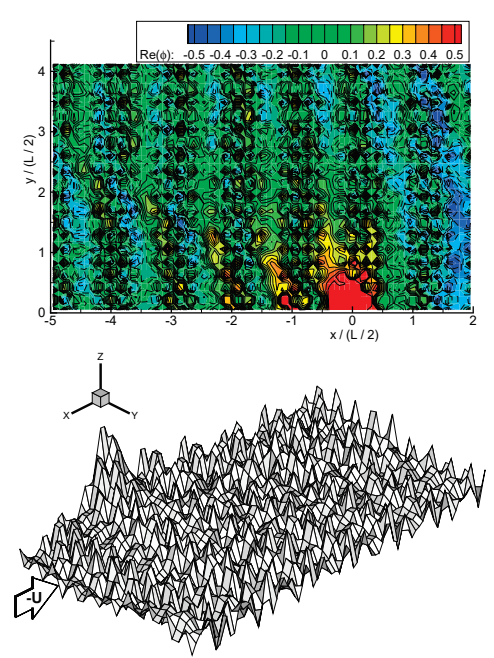

(b) CM with Grid-1

Condition table

\begin{tabular}{|c|c|l|c|}
\hline & Grid & $\begin{array}{l}\text { Dual } \\
\text { conditions at } \\
\text { fore end } \\
\text { points on } S_{F}\end{array}$ & $\begin{array}{l}\text { Condition } \\
\text { on } S_{C}\end{array}$ \\
\hline (b) & Grid-1 & - & CM \\
\hline (c) & \multirow{2}{*}{ Grid-2 } & - & CM \\
\cline { 1 - 2 } (c') & \multirow{2}{*}{ Grid-3 } & $\begin{array}{l}\text { eq. }(16) \\
\left(\zeta=0, \phi_{z}=0\right)\end{array}$ & SCM \\
\hline (d) & \multirow{2}{*}{ (d') } & SCM \\
\hline (e) & \multirow{2}{*}{ Grid-3 } & $\begin{array}{l}S_{F} \text { condi., } \\
\phi_{z}=0\end{array}$ & CM \\
\cline { 1 - 1 } (e') & SCM \\
\hline
\end{tabular}

$\mathrm{CM}$ : Combined method

SCM: Simplified combined method
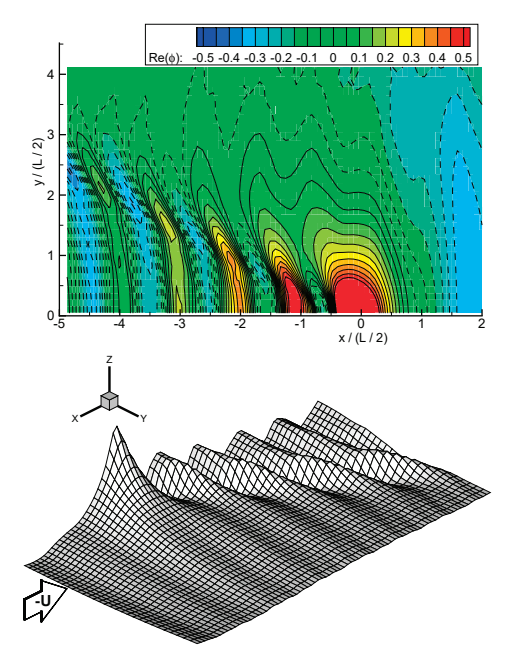

(c) CM with Grid-2
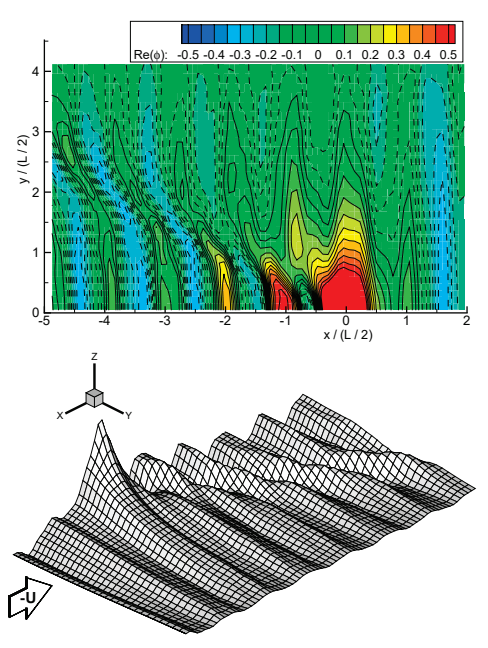

(d) CM with Grid-3

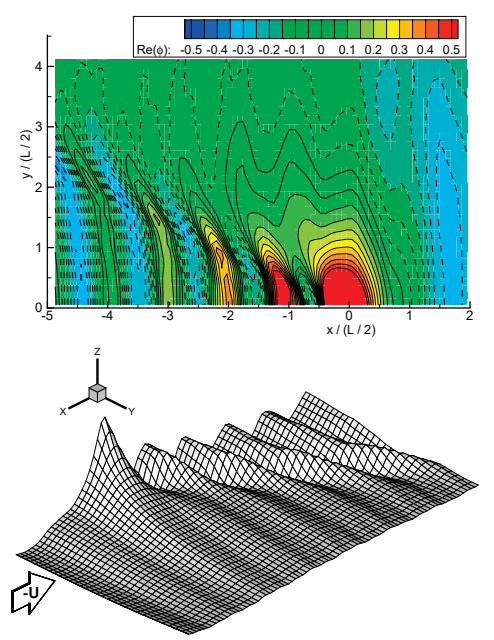

(e) CM with Grid-3
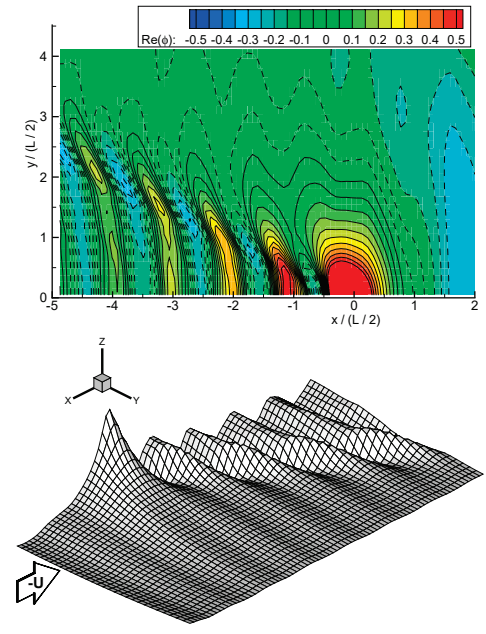

(c') SCM with Grid-2
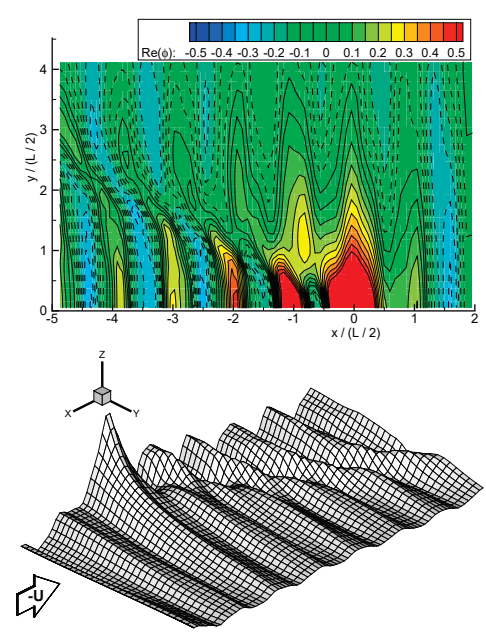

(d') SCM with Grid-3

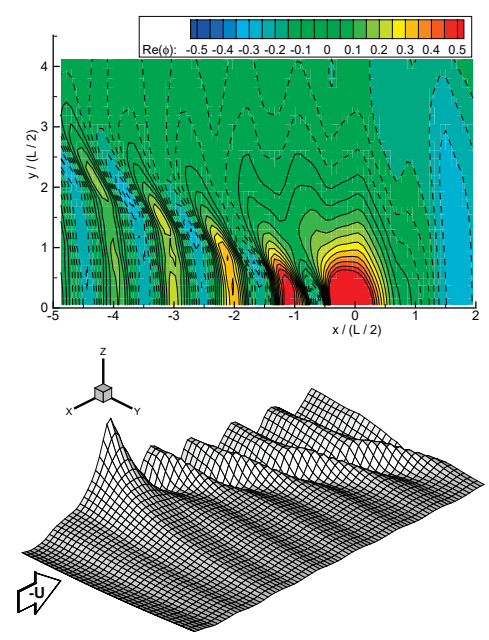

(e') SCM with Grid-3

Fig. 13 Distribution of $\operatorname{Re}[\phi]$ by blend methods of panel-shift method and CM/SCM for $F_{n}=0.2, K_{e} L=1, \tau=0.2$ 
も記したが、今回の単一特異点周りの流場を解く問題において は、 $S_{C}$ 上を含む外部領域の速度ポテンシャルは厳密に $\mathrm{Q}_{0}$ 点 に置かれた特異点により表せることから、(c) と (c')の結果が 同じになるのは当然である。ただ、前節において結合法を近似 化した際に、線積分を完全に無視する扱いにしたが、その影響 がほとんどないということを確認することができる。

(d), (d') は Grid-3 を用いて、 $S_{F}$ の最上流列に Sclavounos \& Nakos の二重条件 (16) を適用し、かつ結合法もしくは簡易 結合法とブレンドした結果である。(c), (c') との相違は、 $S_{F}$ 上での数值的な無限遠条件の与え方の相違にある。計算結果は いずれも良好である。

(e)，(e') は Grid-3 を用いて、 $S_{F}$ の最上流列に 3.2 節 (c) の 条件 (Figs.7(c), 8(c)) を適用し、かつ結合法もしくは簡易結 合法とブレンドした結果である。 3.2 節で示したように、この 二重条件の与え方は、Grid-2 を用いて $S_{F}$ 全域の選点におい て自由表面条件を課す通常のパネルシフト法と数值的に同等の 結果を得ることが分かっている。これと結合法もしくは簡易結 合法とブレンドさせて得られた (e), ( $\left.\mathrm{e}^{\prime}\right)$ の結果は (c), (c') の 結果とほとんど同じになっていることが確認できる。

Fig.13に $F_{n}=0.2, K_{e} L=1.0, \tau=0.2$ の場合の結果を示 している。この場合、 $\tau<1 / 4$ となり、特異点前方にも $k_{2}$ 波 が伝播するようになる。Fig.12の $\tau>1 / 4$ の場合と同様に、 (b) の結合法による結果は細かい波長の波が混在する結果と なり、精度の良い結果が得られているとは言えない。通常の パネルシフト法と結合法もしくは簡易結合法と組み合わせた (c), (c') や、 $S_{F}$ 上流端で通常のパネルシフト法の場合と同等 の結果を得るための二重条件を与える方法 (e), (e’) は、厳密 解である (a) と比べて比較的精度の高い結果を得ることができ ている。一方、 $S_{F}$ 上流端に Sclavounos \& Nakos の二重条件 (16) を適用し、かつ結合法もしくは簡易結合法と組み合わせ た方法である (d), (d') はそれらと比べると不可解な波動場の 振動が顕著となっている。(d), (d') では、 $S_{F}$ 上流端において Sclavounos \& Nakos の二重条件の一つとして $\zeta=0$ の条件が 陽に課されているが、 $\tau<1 / 4$ の場合には $\zeta \neq 0$ であることか ら、この不合理な条件が原因となっているものと推察される。 Sclavounos \& Nakos の二重条件はもともと $\tau>1 / 4$ のみで 適用可能な条件であるので、 $\tau<1 / 4$ の場合にそれを強制的に 課した結果がおかしくても不思議ではない。 $\tau<1 / 4$ の場合に 課すべき適切な二重条件については次節で述べることにする。

以上の計算結果の比較を通じて、無限遠条件をそれなりに 満足した数值解を得ることのできる方法として (c), ( $\left.{ }^{\prime}\right)$ の方 法、あるいは $(\mathrm{e}),\left(\mathrm{e}^{\prime}\right)$ の方法が有効であると結論できる。さ らに計算負荷やプログラムコーディングの容易さまでを考慮に 入れると、(c') の方法が最も良い。 $S_{F}$ と $S_{C}$ との上流端に $x$ 軸方向 1 パネル分の隙間を設けて計算格子を設定 (Grid-2) す るのを嫌うのであれば、( $\left.\mathrm{e}^{\prime}\right)$ でも (c') と同様の結果を得るこ とができる。(c), (d), (e) など結合法を用いる場合、外部領域 はグリーン関数法を用いて定式化されている。よって、周波数 によっては逆行列 $\left[\mathcal{G}_{i j}^{\prime}\right]_{N_{C}}^{-1 N_{C}}$ が不安定となったり、irregular frequency が生じたりすることも懸念され、そうした懸念が無 いという意味でも簡易結合法とブレンドされた (c'), (d'), (e') の方が実用上適している。

\section{6 瀬戸の無限遠条件}

瀬戸は、 2 次元の前進速度を有する非定常造波問題に対して 陽な形の無限遠条件を与えている 23)24)。その結果は、 $x \rightarrow \infty$ の $z=0$ において

$$
\begin{aligned}
(\tau>1 / 4) \text { の場合: } \\
\quad\left(\frac{\partial}{\partial x}-i \lambda_{1}\right) \phi=0 \\
\quad\left(\frac{\partial}{\partial x}-i \lambda_{1}\right)\left(\frac{\partial}{\partial x}-i \lambda_{2}\right) \phi=0 \\
(\tau<1 / 4) \text { の場合: } \\
\quad\left(\frac{\partial}{\partial x}+i k_{2}(\pi)\right) \phi=0 \\
\quad\left(\frac{\partial}{\partial x}+i k_{2}(\pi)\right)\left(\frac{\partial}{\partial x}-i \lambda_{1}\right) \phi=0 \\
\quad\left(\frac{\partial}{\partial x}+i k_{2}(\pi)\right)\left(\frac{\partial}{\partial x}-i \lambda_{1}\right)\left(\frac{\partial}{\partial x}-i \lambda_{2}\right) \phi=0
\end{aligned}
$$

となっている。ただし、

$$
k_{2}(\pi)=\frac{K_{0}}{2}(1-2 \tau-\sqrt{1-4 \tau})
$$

である。ここで、 $\lambda_{1}, \lambda_{2}$ は任意の定数に選べばよいとされて いるので、 $\lambda_{1}=\lambda_{2}=\omega_{e} / U=K_{e} / \tau=K_{0} \tau$ と選べば、上式 は下記となる。

$(\tau>1 / 4)$ の場合:

$$
\begin{aligned}
& \left(\frac{\partial}{\partial x}-i K_{0} \tau\right) \phi=0 \\
& \left(\frac{\partial}{\partial x}-i K_{0} \tau\right)^{2} \phi=0
\end{aligned}
$$

$(\tau<1 / 4)$ の場合:

$$
\begin{aligned}
& \left(\frac{\partial}{\partial x}+i k_{2}(\pi)\right) \phi=0 \\
& \left(\frac{\partial}{\partial x}+i k_{2}(\pi)\right)\left(\frac{\partial}{\partial x}-i K_{0} \tau\right) \phi=0 \\
& \left(\frac{\partial}{\partial x}+i k_{2}(\pi)\right)\left(\frac{\partial}{\partial x}-i K_{0} \tau\right)^{2} \phi=0
\end{aligned}
$$

$\tau>1 / 4$ の場合の (71), (72) は Sclavounos \& Nakos の二 重条件 $(16)$ と全く同一となり、2 次元問題の場合に $x$ 軸上に 存在し得る波数 $k_{1}(0)$ と $k_{2}(0)$ の波が上流側には伝播しないと いう、上流波無しの条件と解することができる 23)24)。

一方、 $\tau<1 / 4$ の場合、 2 次元問題では $x$ 軸上に 4 つの波 数 $k_{1}(0), k_{1}(\pi), k_{2}(0), k_{2}(\pi)$ の進行波が存在し得る。(73) は、 波数 $k_{2}(\pi)$ の波が $x$ 軸正方向に伝播するという Sommerfeld 放射条件を表しており、(74), (75) はそれ以外の進行波が $x$ 軸 上流側へ伝播しないように要請された随伴的条件となっている 23) 24)

上記の上流での陽な無限遠条件と、前節で示した計算法と の関係を考察してみる。 $\tau>1 / 4$ において $(71),(72)$ の条件 を課した計算は、Fig.12 中の $(\mathrm{d}),\left(\mathrm{d}^{\prime}\right)$ になる。その計算結果 

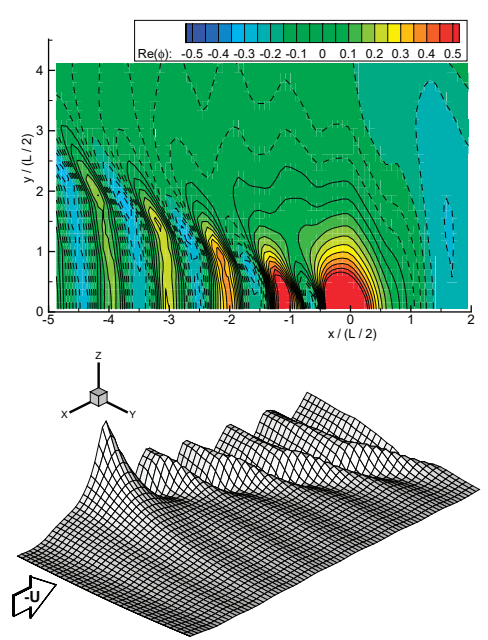

(a) SCM with Grid-3 and Seto's infinite conditions
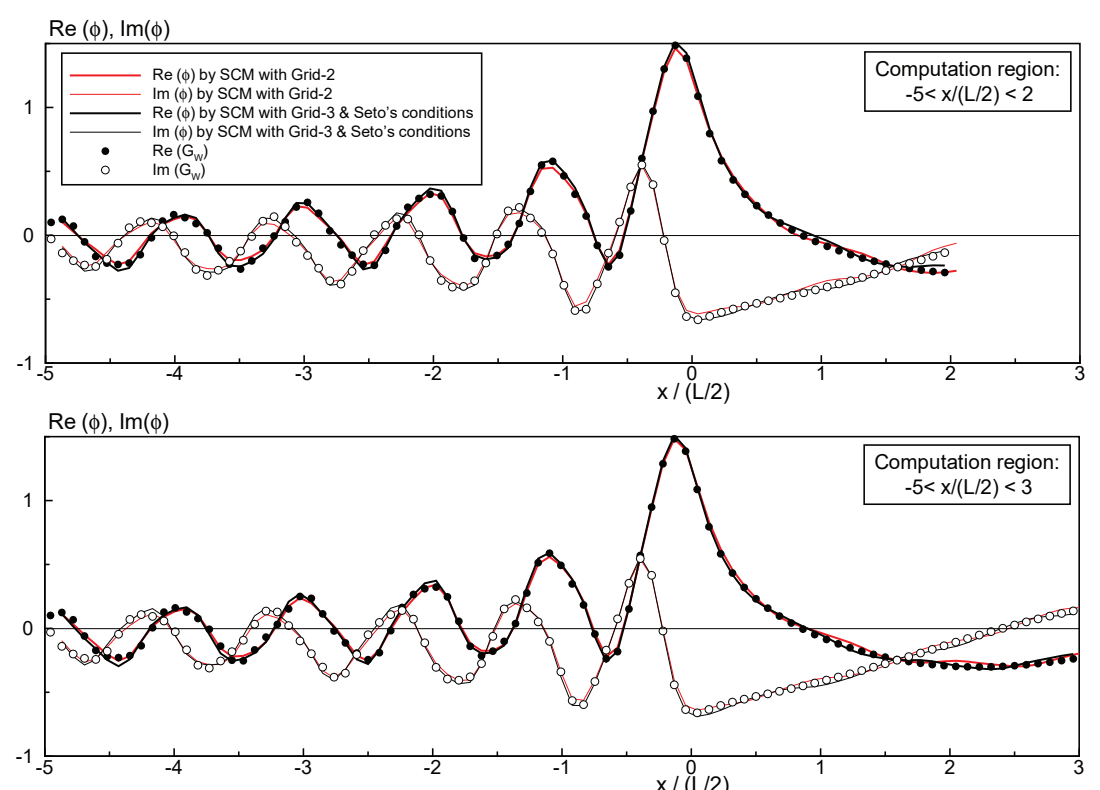

(b) Distribution of $\phi$ on $x$-axis

Fig. 14 Distribution of $\operatorname{Re}[\phi]$ by SCM with Grid-3 and Seto's infinite conditions for $F_{n}=0.2, K_{e} L=1, \tau=0.2$

は厳密解と比べて極めて良好な一致を示していた。(71), (72) は 2 次元問題に対して数学的に導出された条件であるが、(d), (d') の数值計算結果が良好であることは、それを 3 次元問題 へ拡張して使用しても問題がないことを示していると言える。 その際、3 次元問題では計算領域幅方向端から生じる反射波の ような波動を消す必要があり、その手段として、結合法もしく は簡易結合法に基づく $S_{C}$ 上での接合条件が有効であることも 示している。その場合、 $x$ 軸上流では、 $(71),(72)$ の必要条件 の他に、その近傍の $S_{C}$ 上で $(37)$ が追加で課されていること になるが、それにより数值解が扔かしくなることはないことも 分かる。

$\tau<1 / 4$ において (71), (72) の条件を課した計算は、Fig.13 中の (d), (d') であり、その計算結果は厳密解と比べて相違が 大きかった。前記のように、もともと (71), (72)の条件は、 $\tau>1 / 4$ 用であるから、妥当な結果が得られなくても当然で ある。上記のように、 $\tau>1 / 4$ の場合には、 2 次元問題に対し て導出された上流での条件を 3 次元問題に適用することで良 好な結果を得ることができたことから、 $\tau<1 / 4$ においても 同様に、瀬戸の導出した $(73) \sim(75)$ をそのまま 3 次元問題に 適用することで、より良好な数值解を得ることが期待される。 これらの条件のうち、(73) は、 $x$ 軸上流断面の $z=0$ 近傍の $S_{C}$ 上に課した接合条件そのもの、すなわち波数 $k_{2}(\pi)$ の進行 波に関する Sommerfeld 放射条件になっている。よって、残り の 2 条件である $(74),(75)$ を $S_{F}$ 上流端の二重条件として課 せばよいであろう。具体的には、 $\tau>1 / 4$ における (d), (d') の計算に扔いて二重条件として課していた (71), (72)を(74), (75) に入れ替えればよい。その際、二重条件を課す選点近傍
で自由表面条件 $\mathcal{L}[\phi(\mathrm{P})]_{\mu=0}=0$ が精度良く満足されていると すると、(75) は

$$
\left(\frac{\partial}{\partial x}+i k_{2}(\pi)\right)\left(-K_{0} \frac{\partial \phi}{\partial z}\right)=0
$$

と書き直して使用することができるので、核関数 $\tilde{G}(\mathrm{P}, \mathrm{Q})$, $G_{0}(\mathrm{P}, \mathrm{Q})$ の偏微分としては 2 階偏微分までの計算ができれば 事足りる。

こうして得られた計算結果を Fig.14に示している。眓中 (a) と、対応する厳密解 Fig.13(a) や Fig.13 の他の計算結果と比 較してみると、数值解が大幅に改善されていることが分かる。 前節までの結論として、本論文においては Figs.12, 13(c') の方 法、すなわち Grid-2 を用いて通常のパネルシフト法と簡易結 合法 $(\mathrm{SCM})$ とをブレンドした方法を推奨するとしていた。そ こで、その方法と本節の方法による結果を、 $x$ 軸上の速度ポテ ンシャルの分布として定量的に比較して示したのが Fig.14(b) である。(b) の下図には、これまでの計算領域を $x$ 軸上流方向 に少し広くして計算した結果も示している。条件 $(73) \sim(75)$ は、本来 $x \rightarrow \infty$ で課されるべき条件なので、局所波が残って いるような領域で課すのは適切でない。それらの条件を課す場 所の相違が数值解に及ぼす影響を確認するための比較計算であ る。こうして得られた (b) を見ると、二重条件を課す場所の影 響はそれほど顕著ではないものの、計算領域を上流側に広く 取った方が幾分 $x$ 軸上流側の波動の摇らぎが小さいようであ る。また、詳細に見ると、本節の方法の方が、Grid-2 を用い て通常のパネルシフト法と簡易結合法 (SCM) とをブレンドし た方法よりも波動の摇らぎが少なく定量的にも厳密解との合致 が良好であることが分かる。ただ、その相違は非常に僅かで ある。 
以上より、前節および本節を通して推奨する計算法は下記 の 2 種類の方法になる。

手法 1: 計算格子として Grid-2 を使用し、 $x$-shift された $S_{F}$ 上の全ての選点に自由表面条件を課す。かつ $S_{C}$ では 簡易結合法に基づく条件 (37) を課す。

手法 2: 計算格子として Grid-3 を使用し、 $x$-shift されかつ 二重化された $S_{F}$ 上最上流選点では $\tau$ の值に応じて $(71)+(72)$ もしくは (74)+(75) の二重条件を課す。残 りの $S_{F}$ 上の選点には自由表面条件を課す。かつ $S_{C}$ では簡易結合法に基づく条件 (37) を課す。

両方法とも、 $S_{F}$ 上流端で選点を二重化するか否かの相違はあ るものの、 $x$-shift を伴うパネルシフト法と簡易結合法とのブ レンド法となっている。前節で示したように、本来 $x$-shift な どの数值的な手法を必要としない厳密な結合法がなぜ期待する ほど良い結果を与えないのか、またブレンドするとなぜ良い結 果が得られるのかなどに関する数理的な理由が現在のところ不 明であり、今後の研究課題となる。

上記 2 種類の計算法による計算結果に大きな相違はないが、 プログラムコーディング上は手法 1 の方が若干ながら簡単であ る。主には $\tau$ の值により $S_{F}$ 上流端に課す条件式を切り替える 必要がないことに因る。この理由から、後節では、上記に集約 された 2 種類の方法のうち、手法 1 の方法を用いてシリーズ 計算を行うことにする。本節の計算例に見たように、 $\tau<1 / 4$ での計算精度の観点からは、僅かに手法 2 の方法が優れてい ることを注記しておく。

\section{5. 計算例}

\section{1 Rayleigh の仮想摩擦係数}

検査面 $S_{C}$ を設けずに無限遠条件 (ただし減衰を伴う) を満 足させる方法として、パネルシフト法を用いつつ、自由表面条 件演算子 (3) 中の Rayleigh の仮想摩擦係数 $\mu$ を数值的に与え る方法が考えられる。上流差分法をベースに $\mu$ を取り入れた 安川 ${ }^{6)}$ の方法と類似の方法になる。本論文で提案する方法と 比較する目的でこの方法も試してみることにする。

高木 ${ }^{5)}$ の研究により、 $\mu$ は計算格子が荒くなるほど大きな 值を設定すべきであることが分かっている。一般に、ランキン パネル法では船体から離れるに従い計算格子を粗に分割するの で、遠方に行くに従い $\mu$ を大きくすべきということになる。ま た、この $\mu$ は $\tau$ が大きく、造波が下流側のみに起こる場合に は不要となる。パネルシフト法による無限遠条件と二重に条件 を課すことにならないように処置する必要がある。計算領域が 決まれば、その領域の下流側に造波が起こる $\tau$ の範囲が決ま る。後述の計算例に示す計算領域の場合には、 $\tau=0.4 \sim 0.5$ において、造波された波が計算領域下流側上辺 $(y$ 軸最大とな る位置) に掛かり出す。以上を考慮して次式で $\mu$ を与えること にしている。

$$
\mu(\tau, R)=f_{1}(\tau) f_{2}(R), \quad R=\sqrt{x^{2}+y^{2}}
$$

ただし、 $\tau_{s}=0.4, \tau_{e}=0.5, t=1-\left(\tau-\tau_{s}\right) /\left(\tau_{e}-\tau_{s}\right)$ とす るとき

$$
f_{1}(\tau)=\mu_{c} \begin{cases}1 & \left(\tau \leq \tau_{s}\right) \\ 6 t^{5}-15 t^{4}+10 t^{3} & \left(\tau_{s}<\tau<\tau_{e}\right) \\ 0 & \left(\tau \geq \tau_{e}\right)\end{cases}
$$

である。また、 $s=R / R_{c}$ とするとき

$$
f_{2}(R)= \begin{cases}a_{4} s^{4}+a_{3} s^{3}+a_{2} s^{2} & (0<s<1) \\ 1 & (s \geq 1)\end{cases}
$$

であり、 $f_{2}(0)=f_{2}^{\prime}(0)=0, f_{2}(1)=f_{2}^{\prime}(1)=0, f_{2}(1 / 2)=$ 0.32 を満足するように $a_{2} \sim a_{4}$ を決めている。後述の計算例 では $\mu_{c}=0.3, R_{c}=7$ としている。こうして $\mu(\tau, R)$ は特異 点近傍 (点 $Q_{0}$ に置かれた造波源) では効きが弱く、 $R$ が大き くなるほど $f_{1}(\tau)$ に近づくようにしている。なお、 $\mu(\tau, R)$ は (3) の $i \mu K_{e}$ にのみ作用させる ${ }^{6) 。}$

\section{2 無限遠条件の異なる各種計算法の計算結果}

Figs. 15〜22 に計算例を示している。計算に使用した計算格 子は、Fig.11(b) に示した Grid-2 と同じ形であるが、本節で は、 $S_{C}$ を十分遠方に取ることを仮定した Sommerfeld 型放射 条件 (34) や接合条件 (37) を適用した計算を行うことから、計 算領域を広めに設定している。 $S_{F}$ は、 $x$ 軸方向に対して $y$ 軸 方向を 1.2 倍とした領域であり、各々の方向に 80 分割、50 分 割している。 $x$ 軸方向のパネル引き寄せは行っていない。 $S_{C}$ の深さの決め方および分割数については、Fig. 11(b) と同様で ある。 $S_{C}$ を必要としない計算法においては、Grid-2 の $S_{F}$ 部 分のみを使用する。

図中に示した $(\mathrm{a}) \sim(\mathrm{e})$ の計算法は下記を意味している。

(a) (1) の波核関数 $G_{W}$ の計算であり、ここでは厳密解と見 做す。

(b) Grid-2 の $S_{F}$ 部のみを使用した通常のパネルシフト法。

(c) Grid-2 の $S_{F}$ 部のみを使用した通常のパネルシフト法に おいて、(77)の $\mu$ を導入した計算。

(d) 4.6 節最後に述べた手法 1 。Grid- $2\left(S_{C}\right.$ 含む) を使用し、 通常のパネルシフト法と簡易結合法をブレンドした計算 法となる。ただし、接合条件 $(37)$ の $\alpha(\mathrm{P})$ は漸近波理論 の停留点を用いて計算する。 $S_{C}$ 上で Sommerfeld 放射 条件 (34) を課す Das ら 10) や Yuan ら 11) と同じ方法と 見なしてよい。ただし、彼らは上流差分をべースとして いるため、短波長波の分解能はここで示す計算結果より 低いと思われる。

(e) 4.6 節最後に述べた手法 1 そのもの。接合条件 (37) の $\alpha(\mathrm{P})$ は厳密解 $G_{W}$ を用いて (36) より計算する。

Figs. $15 \sim 17$ は $\tau$ が大きい場合の例である。Fig. 15 のよ うに造波が計算領域幅方向の端に掛からない場合にはいずれ の計算法も良好な結果になっていることが分かる。ただし、 $\mu$ を入れた計算は、その減衰効果で原点から遠方での波振幅が若 干小さ目になっている。 

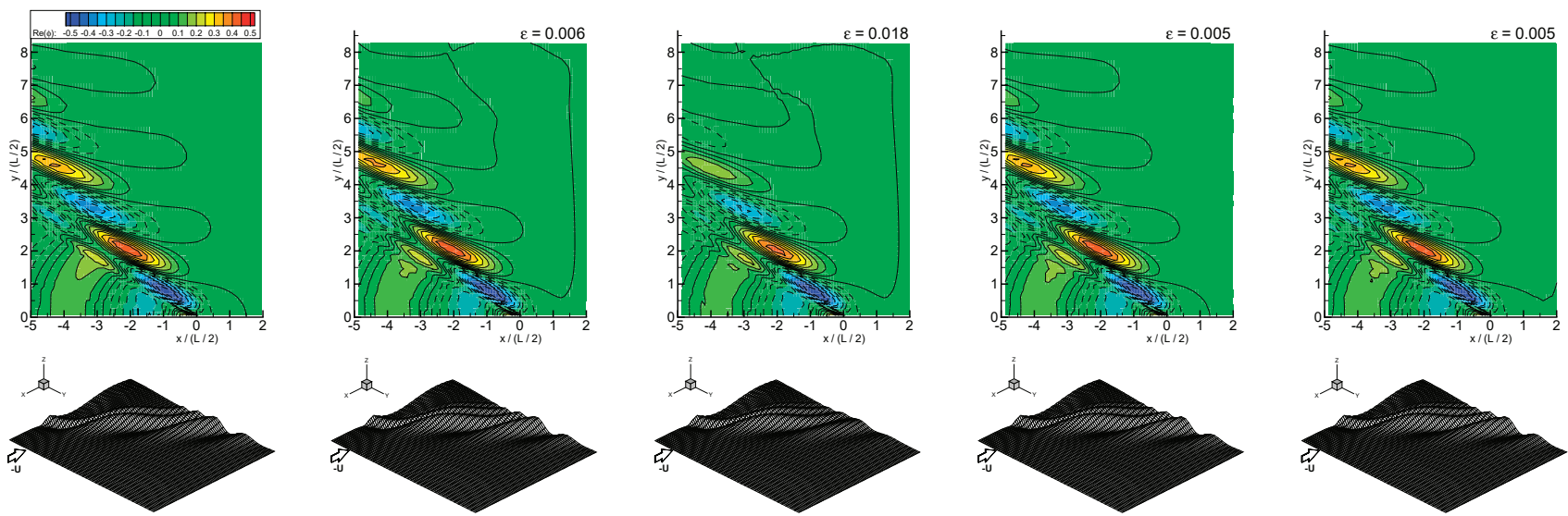

(a) Wave source

(b) Ordinary

(c) Ordinary $+\mu$

(d) with $S_{C}$ (asym.)

(e) with $S_{C}\left(G_{W}\right)$

Fig. 15 Distribution of $\operatorname{Re}[\phi]$ by RPMs with different numerical infinite condition for $F_{n}=0.2, K_{e} L=5.0, \tau=0.447$

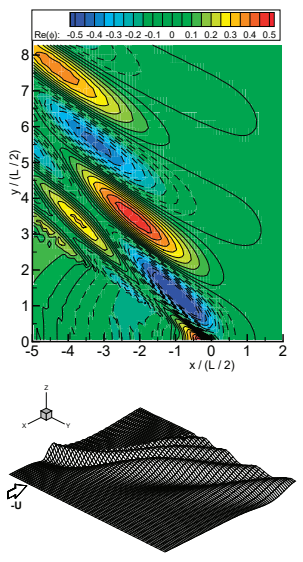

(a) Wave source

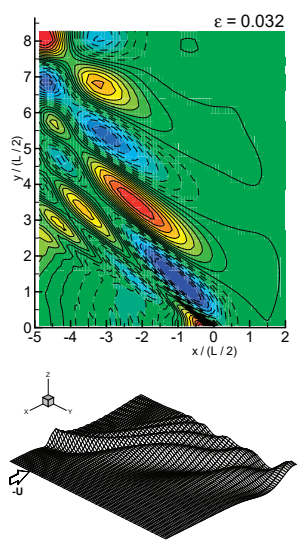

(b) Ordinary
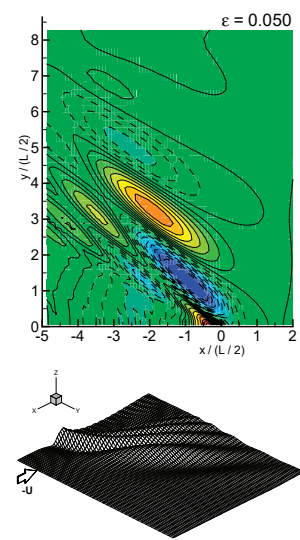

(c) Ordinary $+\mu$
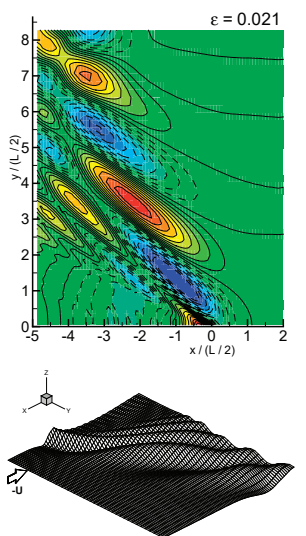

(d) with $S_{C}$ (asym.)
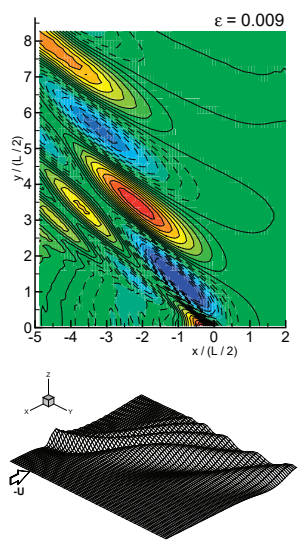

(e) with $S_{C}\left(G_{W}\right)$

Fig. 16 Distribution of $\operatorname{Re}[\phi]$ by RPMs with different numerical infinite condition for $F_{n}=0.2, K_{e} L=3.0, \tau=0.346$

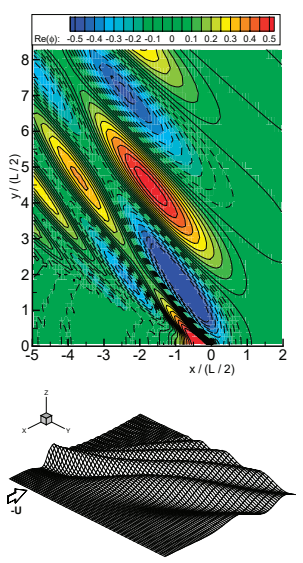

(a) Wave source

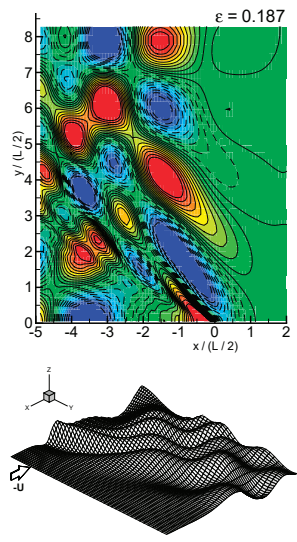

(b) Ordinary
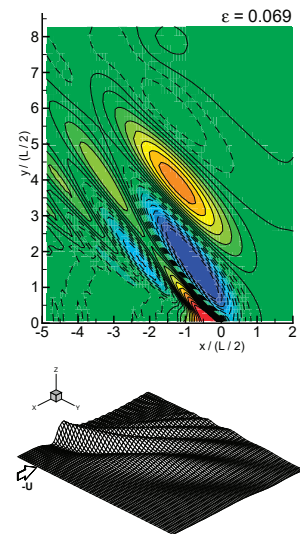

(c) Ordinary $+\mu$
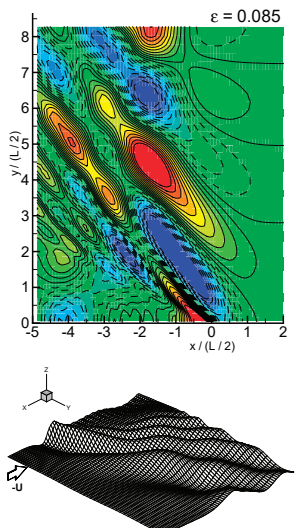

(d) with $S_{C}$ (asym.)
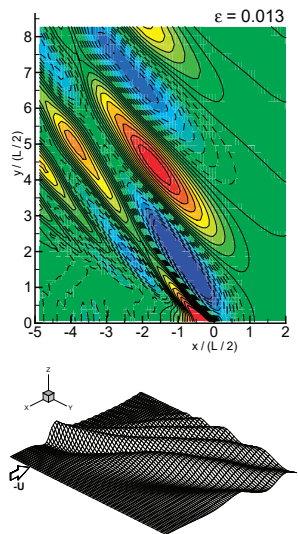

(e) with $S_{C}\left(G_{W}\right)$

Fig. 17 Distribution of Re[ $[\phi]$ by RPMs with different numerical infinite condition for $F_{n}=0.2, K_{e} L=2.25, \tau=0.3$

Figs. 16, 17 のように造波が計算領域幅方向の端に掛かるよ うになると各計算法の違いが明確になる。(b) の通常のパネル シフト法では計算領域端からの反射波のような波動が現れるの に対して、(c)〜(e) ではそのような波動が現れなくなる。 $S_{C}$ 上の接合条件の $\alpha(\mathrm{P})$ を漸近波理論の停留点を用いた計算する (d)では、(a)の厳密解と比べて計算領域端部で不自然な波の 摇らぎが見受けられるが、本論文で推奨する $(\mathrm{e})$ の方法ではそ のような不自然な波が現れない。(a)の厳密解との合致は極め て良好である。

Figs. 18, 19 は $\tau$ が 0.25 に極めて近い場合の例である。こ 

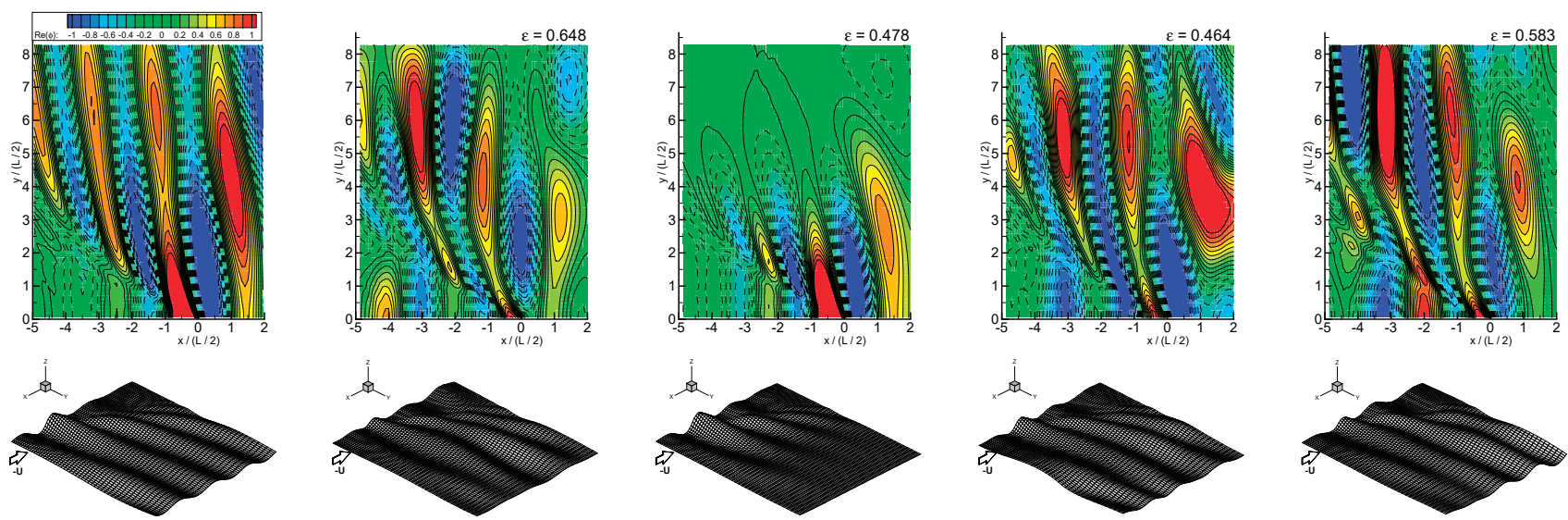

(a) Wave source

(b) Ordinary

(c) Ordinary $+\mu$

(d) with $S_{C}$ (asym.)

(e) with $S_{C}\left(G_{W}\right)$

Fig. 18 Distribution of $\operatorname{Re}[\phi]$ by RPMs with different numerical infinite condition for $F_{n}=0.2, K_{e} L=1.575, \tau=0.251$

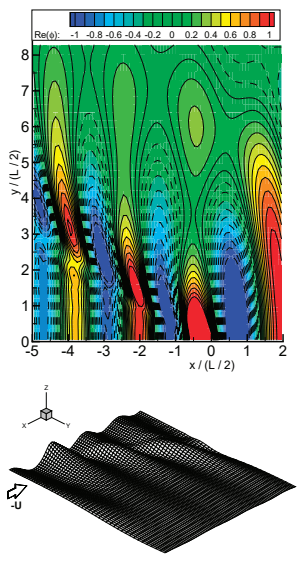

(a) Wave source
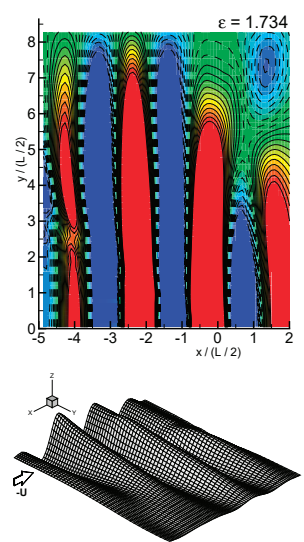

(b) Ordinary
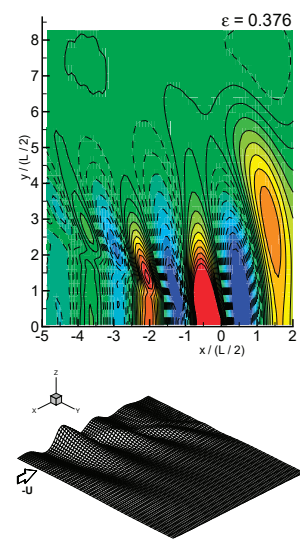

(c) Ordinary $+\mu$
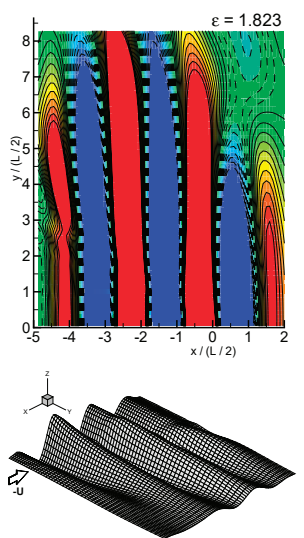

(d) with $S_{C}$ (asym.)
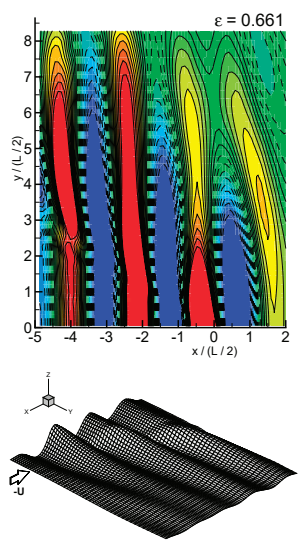

(e) with $S_{C}\left(G_{W}\right)$

Fig. 19 Distribution of $\operatorname{Re}[\phi]$ by RPMs with different numerical infinite condition for $F_{n}=0.2, K_{e} L=1.55, \tau=0.249$
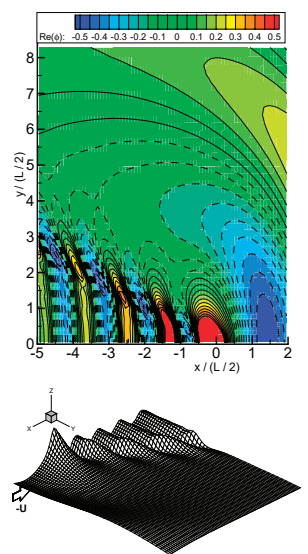

(a) Wave source
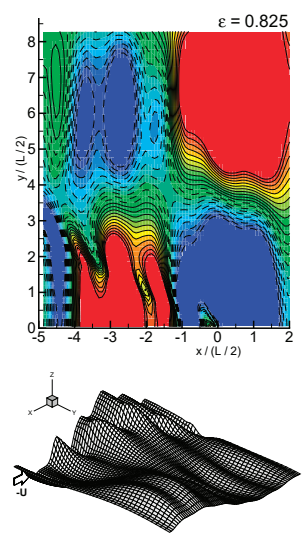

(b) Ordinary
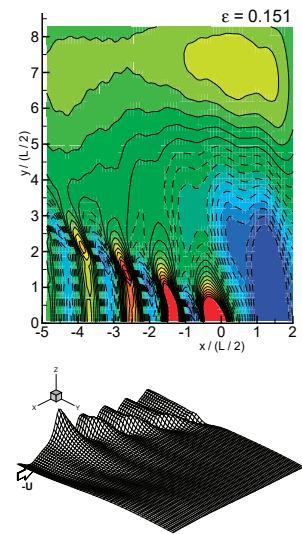

(c) Ordinary $+\mu$
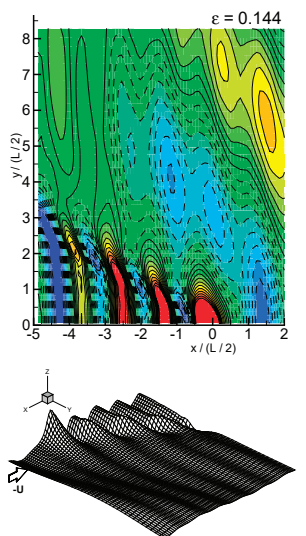

(d) with $S_{C}$ (asym.)
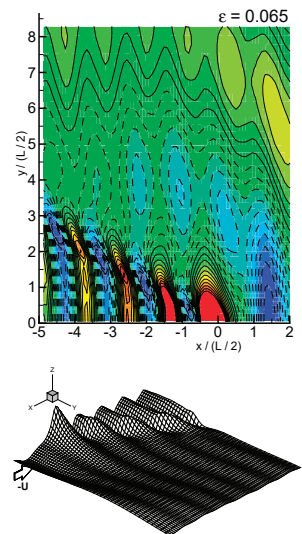

(e) with $S_{C}\left(G_{W}\right)$

Fig. 20 Distribution of $\operatorname{Re}[\phi]$ by RPMs with different numerical infinite condition for $F_{n}=0.2, K_{e} L=1.266, \tau=0.225$

の $\tau$ の領域では速度ポテンシャル $\phi$ の值がかなり大きくなる ので、等高線のレベルを \pm 1.0 の範囲で、鳥譀図の縦軸を他の $1 / 4$ 倍のスケールで描いている。Figs. 18 は $\tau>0.25$ であり、 Fig. 10(b) に示した漸近波紋図における $\theta_{22}$ に対応する波が非 常に顕著に現れていることが分かる。円環波系に対応する $\theta_{21}$
の波は明瞭には見られない。Fig. 19 は $\tau<0.25$ であり、漸近 波理論では $k_{2}$ 波が円環波系へと変化するが、Figs. 18 と 19 の 厳密解 (a) を見ると、その変化は突然生じるのではなく徐々に 変化して行くように見える。

Figs. 20 22 は $\tau<0.25$ の例であり、 $k_{2}$ 波は円環波系の波 

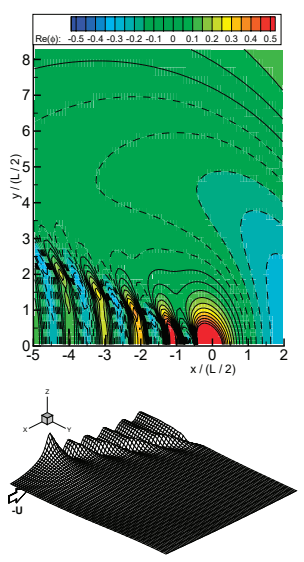

(a) Wave source

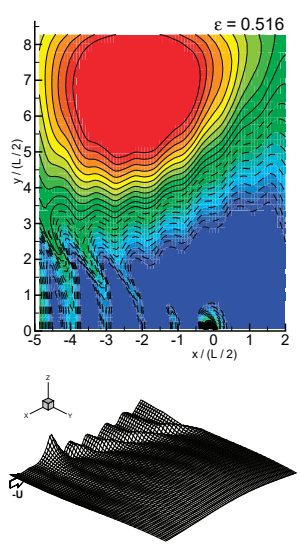

(b) Ordinary
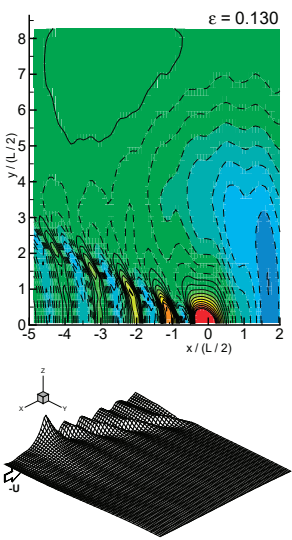

(c) Ordinary $+\mu$
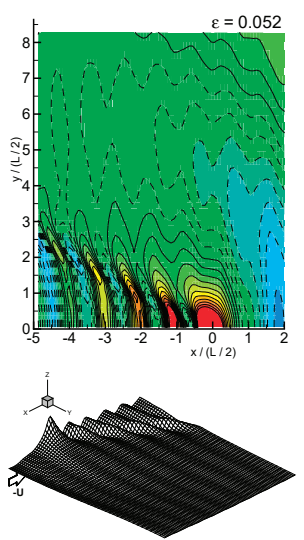

(d) with $S_{C}$ (asym.)
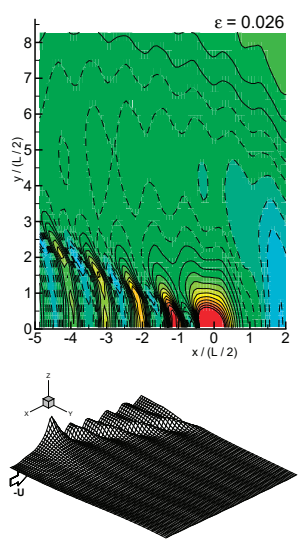

(e) with $S_{C}\left(G_{W}\right)$

Fig. 21 Distribution of $\operatorname{Re}[\phi]$ by RPMs with different numerical infinite condition for $F_{n}=0.2, K_{e} L=1.0, \tau=0.2$

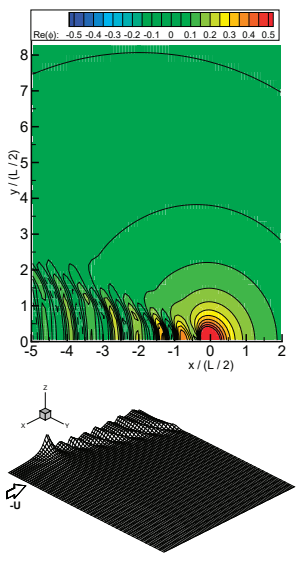

(a) Wave source

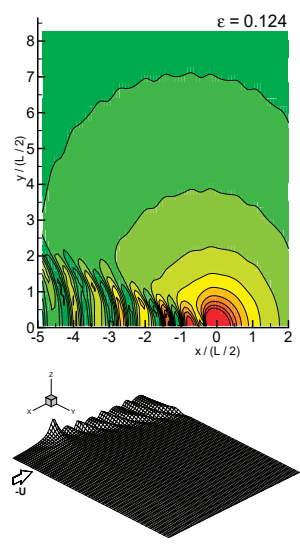

(b) Ordinary

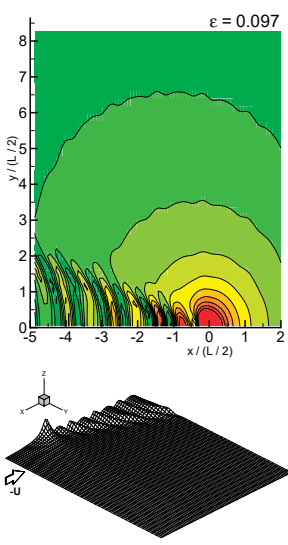

(c) Ordinary $+\mu$

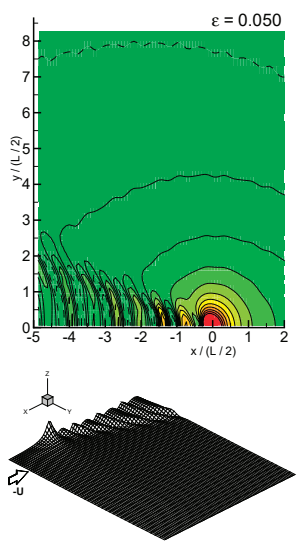

(d) with $S_{C}$ (asym.)

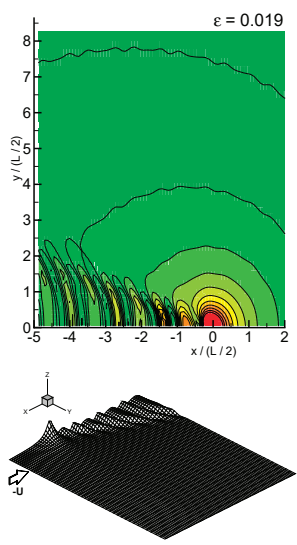

(e) with $S_{C}\left(G_{W}\right)$

Fig. 22 Distribution of Re[ $\phi]$ by RPMs with different numerical infinite condition for $F_{n}=0.2, K_{e} L=0.25, \tau=0.1$

となる。通常のパネルシフト法 (b) は、この $k_{2}$ 波に対する無 限遠条件を何ら考慮しないこともあり、Figs. 20,21 ではおか しな結果となる。 $S_{C}$ 上で接合条件を課す $(\mathrm{d})$ や $(\mathrm{e})$ は、厳密 解 (a) に近い結果を与えている。特に (e) は良好な推定值を与 えている。(d)や (e) の結果には、 $y$ が大きい箇所において $x$ 軸方向への波動が若干残るようである。 $\mu$ を導入した (c) の結 果では、強い減衰効果によりこうした波動が見られない。

波動場の推定精度を評価する指標を定めるのは難しいが、厳 密解と比べた誤差は一つの定量的な指標となるであろう。各図 の右上に記した $\varepsilon$ は次式で定義される誤差平均值である。

$$
\varepsilon \equiv \frac{1}{N} \sum_{i=1}^{N}\left|\phi\left(\mathrm{P}_{i}\right)-G_{W}\left(\mathrm{P}_{i}, \mathrm{Q}_{0}\right)\right|
$$

$N$ は自由表面のパネル数である。

この指標に着目して Figs. $15 \sim 22$ を総合的に見ると、 $\tau \cong$ 0.25 の Figs. 18, 19 以外では (e) の計算法が最も誤差平均值が 小さくなっており高精度であると言える。Figs. 18, 19 でも他 と比べて極端に誤差平均值が低下する訳ではなく、波動の定 性的な観点も含めれば総合的に優位にあると言えるであろう。 $\mu$ を導入する方法は、 $\mu$ を小さく設定すると計算領域端からの 反射波のような波動が現れるため、遠方で波振幅がゼロになる 程度に十分に大きく設定する必要があり、その強い減衰効果 により遠方で波振幅が小さくなる。しかし、本論文のように $\mu$ を $R$ の関数として変化させて与えることで、特異点近傍の 波の減衰は抑えられるし、検査面 $S_{C}$ が不要であるので計算 負荷は小さい。もともと安川 ${ }^{6)}$ が上流差分法と $\mu($ 領域内一定 值)を組み合わせる形で提案した方法であるが、近場の推定に 限れば実用的な方法と言えるかも知れない。

(e) の計算、すなわち本論文で推奨する手法 1 による計算で は、 $S_{F}$ 上の選点の $x$-shift による無限遠条件と、 $S_{C}$ 上で接合 条件を課すことによる無限遠条件を二重に課している。Fig. 15 のように、造波が計算領域幅方向端に掛からないような $\tau$ の 範囲では、本来前者による無限遠条件のみで十分のはずであ り、後者の条件は不要である。Fig. 15 に見るように、不要な 条件を追加で課したことにより数值解に悪影響が出るようなこ とは全くないようである。ただ、計算負荷の観点からは、計 算領域幅方向の端に造波が掛からない $\tau$ の範囲では検査面 $S_{C}$ を組み込まずに計算した方が経済的である。 
Table 1 Principal dimensions of the model

\begin{tabular}{|c|l||c|l|}
\hline$L_{p p}(\mathrm{~m})$ & 2.500 & $K G(\mathrm{~m})$ & 0.151 \\
$B(\mathrm{~m})$ & 0.385 & $G M_{L}(\mathrm{~m})$ & 3.394 \\
$d(\mathrm{~m})$ & 0.140 & $\kappa_{y y} / L_{p p}$ & 0.251 \\
$\nabla\left(\mathrm{m}^{3}\right)$ & 0.0813 & $x_{B}=x_{G}(\mathrm{~m})$ & -0.056 \\
$C_{b}$ & 0.604 & $z_{B}(\mathrm{~m})$ & -0.062 \\
$L C B(\mathrm{~m})$ & $0.056(\mathrm{aft})$ & $z_{G}(\mathrm{~m})$ & 0.011 \\
\hline
\end{tabular}

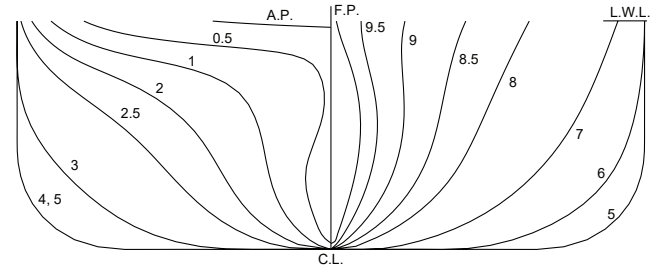

Fig. 23 Body plan of RIOS container
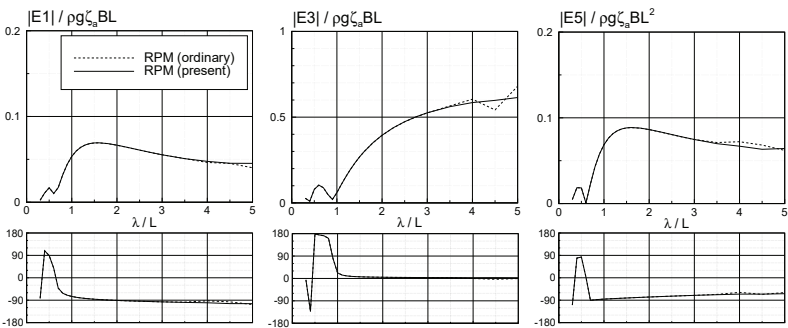

(a) Wave exciting forces

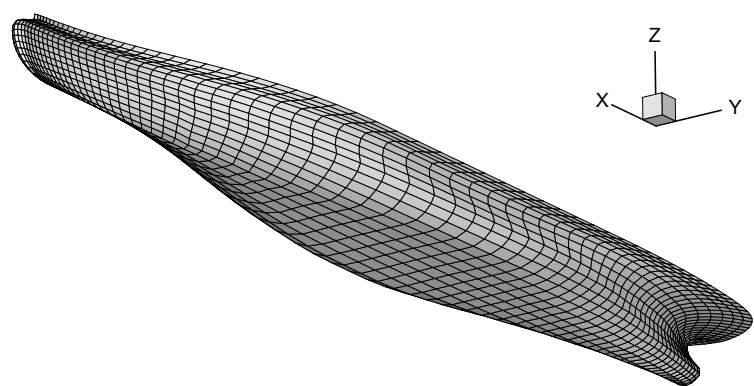

Fig. 24 Computation grid for RIOS container
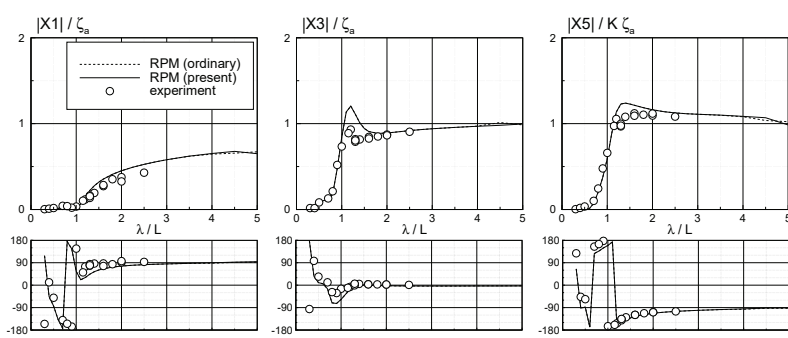

(b) Ship motions

Fig. 25 Wave exciting forces and ship motions for RIOS container at $F_{n}=0.18, \chi=180$ degs.

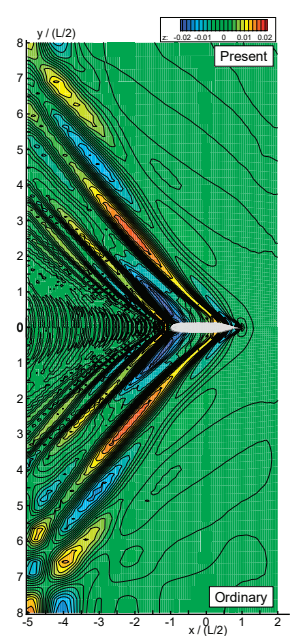

(a) $\lambda / L=3.0$,

$\tau=0.328$

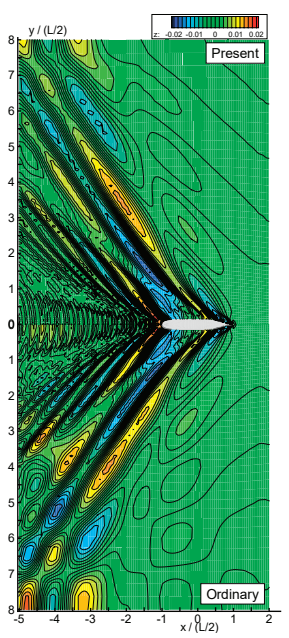

(b) $\lambda / L=3.5$,

$\tau=0.299$

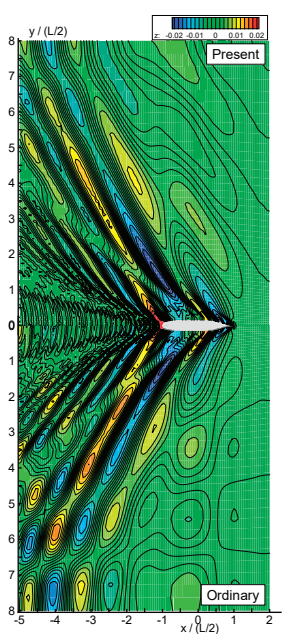

(c) $\lambda / L=4.0$,

$\tau=0.276$

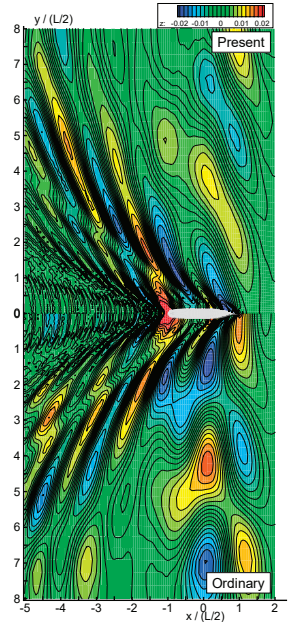

(d) $\lambda / L=4.5$,

$\tau=0.258$

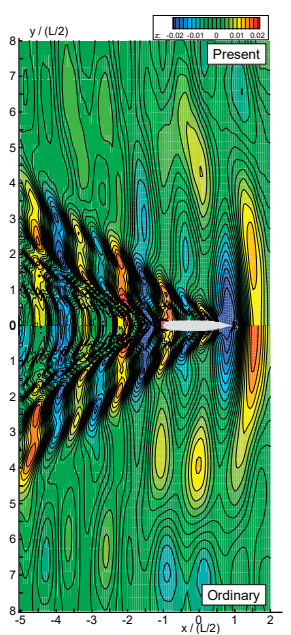

(e) $\lambda / L=5.0$,

$\tau=0.242$

Fig. 26 Unsteady waves around a RIOS container at $F_{n}=0.18, \chi=180$ degs., $H / \lambda=1 / 20$ (cos component)

頁数の関係で本論文では割愛するが、(e)の計算法は前進速 度なしの場合に対しても高精度の解を与えることを確認して いる。前進速度なしの場合には、 $S_{F}$ 上での $x$-shift を止めて、 (1) の波核関数 $G_{W}$ として前進速度なしの波核関数を用いれ ばよく、アルゴリズム的には前進速度に応じてその切り替えを 行えば良いのみである。

\section{3 実船への適用例}

最後に実船への適用例を示しておく。対象船型は RIOS (Research Initiative on Oceangoing Ships) において供試模 型として製作・実験されたコンテナ船である。主要目と Body plan を Table 1, Fig. 23 に、計算格子を Fig. 24 に示す。本計 算では $L$ として Table 1 の垂線間長 $L_{p p}$ を用いる。

船体は片舷で 1050 分割 (船長方向 70 分割、ガース方向 15 分割) されている。自由表面 $S_{F}$ は $6384(x$ 軸方向 $133 \times y$ 軸 
方向 48)、検査面 $S_{C}$ は 810 (周方向 $81 \times$ 深さ方向 10) に分 割している。この計算においては船首尾でのパネル引き寄 せは行っていない。 $S_{C}$ 上での $\alpha(\mathrm{P})$ は、船長方向特異点分 布 $\int_{-L / 2}^{L / 2} G_{W}\left(\mathrm{P}, \mathrm{Q}_{0}\right) d x^{\prime}, \int_{-L / 2}^{L / 2} \partial G_{W}\left(\mathrm{P}, \mathrm{Q}_{0}\right) / \partial n_{\mathrm{P}} d x^{\prime}, \mathrm{Q}_{0}=$ $\left(x^{\prime}, 0, z_{B}\right)\left(z_{B}\right.$ :浮心座標 $)$ を $(36)$ の右辺、左辺に用いて計算し ている。境界值問題の定式化は、基礎流場を二重模型流れとし たものに則している ${ }^{13)}$ (自由表面条件は安川型 6) を採用)。

Fig. 25 に波強制力と運動の結果を示している。 $\lambda / L>3$ の 範囲では $\tau$ が小さくなり造波が計算領域幅方向の端に掛かる ようになる。このため通常のパネルシフト法では波強制力など 流体力に不自然な振動が見られるようになる。本論文で推奨す る手法 1 に基づき、 $S_{C}$ 上で接合条件を課すことでそうした現 象がなくなっていることが分かる。結果として運動の結果も改 善する。なお、運動の実験結果は、九州大学応用力学研究所深 海機器力学実験水槽において、著者の研究室と大阪大学柏木研 究室との共同実験により計測されたものである。

Fig. 26 には低周波数域で動摇しながら前進する船体まわり の非定常波の $\cos$ 成分を、通常のパネルシフト法と本論文の方 法と比較して示している。単一特異点の場合と同様に、計算領 域幅方向の端からの反射波のような波動現象が解消されている ことが確認できる。

\section{6. 結 言}

本研究では、周波数領域ランキンパネル法における低速/低周 波数域での無限遠条件に関し、その数值計算上の処理法につい て検討した。本研究を通して得られた結論を示すと以下のよう になる。

(1) 数值的な無限遠条件の処理法が異なる既存の各種ランキ ンパネル法を用いて、単一特異点まわりの波動場を求め 厳密解と比較した。その結果、スプライン要素法が最も 高精度であることが分かったが、 $\tau$ が小さい場合の計算 領域端からの反射波のような波動現象はどの方法でも現 れることが確認された。

(2) パネルシフト法とスプライン要素法は、共に自由表面上の 選点を $x$-shift する方法であるという意味において類似の 計算法であることが確認された。また、パネルシフト法 において $z$-shift を取り入れることにより、計算される波 角が修正され、スプライン要素法と同等の計算精度が得 られることが分かった。加えて、パネルシフト法におい て、解像度を上げたい箇所に自由表面上のパネルを引き 寄せて計算しても計算精度の低下などの問題が生じない ことも確認された。これらは実用上、有益な情報である。

(3) 漸近波理論から Sommerfeld 型放射条件を導出し、それ がDas らや Yuan らが円環波のドップラーシフトの概念 から求めた結果を包含する一般的なものであることを示 した。同時に彼らの方法の不合理な点も明確化された。 また、より合理的な条件への拡張を行うと、その条件式
が特異点近傍の内部解と遠方の外部解とを検査面上で結 びつける接合条件と見做すことができることが示された。

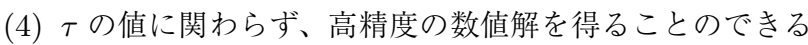
手法として 2 種類の方法を提案した。一つは通常のパネ ルシフト法と簡易結合法とをブレンドする方法 (本文中 の手法 1)、もう一つは、パネルシフト法に扔いて自由表 面最上流列の選点を二重化し、そこに瀬戸が 2 次元問題 で導出した条件を適用するとともに簡易結合法とブレン ドする方法 (本文中の手法 2) である。両手法はほとんど 同じ結果を与える。また、手法 1 を用いて単一特異点ま わりの波動場を計算した例を示し、既存の計算法の中で 最も高精度であることを示した。

（5）同方法を実船に適用した計算を行い、本手法により $\tau$ の 小さい領域における計算が合理的な結果を与えることを 確認した。

本手法により低周波数域での波動場の推定精度が改善できたこ とから、今後は耐航性能の推定で数值計算精度上最も難しい抵 抗増加の推定精度向上に注力したい。

なお、本論文で提案した計算法は、数值解を改善するため の無限遠条件の数值的取り扱いに関する一方法に過ぎない。 $\tau \cong 1 / 4$ での計算精度を更に高める方法の開発も必要である し、本論文で提案した方法がうまくいく理由など数理的な観点 からの探究も必要である。

\section{謝 辞}

本研究の一部は科学研究費基盤研究 (B)26289333、基盤研究 (A)25249127、基盤研究 (A)23246151 および九州大学応用力 学研究所共同利用研究、RIOS プロジェクトにより遂行された ことを記し、関係各位に謝意を表わします。

\section{参 考文 献}

1) Bertram, V.: Ship motions by a Rankine source method, Ship Tecnology Research, Vol. 37, pp. 143-152 (1990)

2) 安東 潤，中武一明: Rankine Source 法による流れの一 計算法，西部造船会々報，第 75 号，pp. 1-12 (1988)

3) Jensen, G., Bertram, V. and Soeding, H.: Ship waveresistance computations, Proc. 5th International Conference on Numerical Ship Hydrodynamics, Hiroshima, pp. 593-606 (1989)

4) Sclavounos, P. D. and Nakos, D. E.: Ship motions by a three-dimensional Rankine panel method, Proc. of 18th Symposium on Naval Hydrodynamics, Ann Arbor, pp. 21-40 (1990)

5) 高木 健：Rankine Source 法による非定常波動問題の計 算について, 関西造船協会誌, 第 213 号 (1990) 
6) Yasukawa, H.: A Rankine Panel Method to Calculate Unsteady Ship Hydrodynamic Forces, J. Soc. Naval Arch. Japan, No.168, pp.131-140 (1990)

7) Dawson, C.W.: A Practical Computer Method for Solving Ship-Wave Problems, Proc. of 2nd International Conference on Numerical Ship Hydrodynamics, Univ. California, Berkeley, pp. 30-38 (1977)

8) Iwashita, H., Lin X., Takaki M. : Combined BoundaryIntegral Equation Method for Ship Motion in Waves, 西部造船会々報, 第 85 号 (1993)

9) 柏木 正, 岩下英嗣, 高木 健, 安川宏紀: 耐航性理論 の設計への応用「第 3 章 三次元理論による計算」, 運 動性能研究委員会第 11 回シンポジウム, 日本造船学会, pp. 219-292 (1994)

10) Das, S., Cheung, K.F.: Scattered Waves and Motions of Marine Vessels Advancing in a Seaway, Wave Motion 49(1), pp. 181-197 (2012)

11) Yuan, Z.M., Incecik, A., Jia, L.: A New Radiation Condition for Ships Travelling with Very Low Forward Speed, Ocean Engineering, Vol. 88, pp. 298-309 (2014)

12) Bessho, M. : On the Fundamental Singularity in a Theory of Motions in a Seaway, Memoirs of the Defense Academy Japan, Vol. XVII, No. 8 (1977)

13) 柏木 正, 岩下英嗣：船舶海洋工学シリーズ 4 船体運動耐 航性能編, 成山堂書店, 10 月 28 日発刊 (2012)

14）岩下英嗣, 大楠 丹: 特異点法による波浪中を航走する船 に作用する流体力の研究, 日本造船学会論文集, 第 166 号, pp. 187-205 (1989)

15）岩下英嗣, Muniyandy Elangovan, 柏木 正, 笹川拓真: 波浪中を前進する船の非定常波形解析について，日本船 舶海洋工学会論文集, Vol.13, pp.95～106 (2011)

16) Y. Cao, W. W. Schultz, R. F. Beck: A Three - Dimensional Disingularized Boundary Integral Method for Potential Problems, International Journal of $\mathrm{Nu}$ merical Methods in Fluids, 11:785-803 (1991)

17) R. F. Beck, Y. Cao, T.-H. Lee: Fully Nonlinear Water Wave Computations Using the Desigularized Mathod, Proceedings 6th Interntional Conference on Naval Hydrodynamjics, Univ. of Iowa (1993)

18）瀬戸秀幸: 定常造波問題における Rankine Source 法の基 礎と開境界条件処理に関する一考察, 西部造船会々報, 第 81 号, pp. 11-28 (1991)

19) Bai, K. J., Yueng R.: Numerical Solutions to FreeSurface Flow Problems, 10th Symposium on Naval Hydrodynamics, Office of Naval Research, MIT, Cambridge, Mass, USA, pp.609-633 (1974)
20) 吉田基樹, 一色 浩, 鮑 偉光, 木下 健 : 高次オーダー速 度ポテンシャルの解法 - 波漂流付加質量の理論計算 - , 日 本造船学会論文集, 第 194 号, pp.119-127 (2003)

21) H. Iwashita, M. Takaki, X. Lin: A Hybrid Method to Solve the Boundary Value Problem of a Ship Running and Oscillating in Waves, Mini-Symposium on Nonlinear and Free-Surface Flows, Hiroshima Univ. (1992)

22) H. Iwashita, X. Lin, M. Takaki: Combined BoundaryIntegral Equation Method for Ship Motions in Waves, Transactions of the West-Japan Society of Naval Architects, No. 85, pp.37-55 (1993)

23）瀬戸秀幸：一様流中での周期的水面波動問題に伴う開境界 条件の陽な表現について, 第 55 回理論応用力学講演会論 文集, 2F06 (2006)

24）瀬戸秀幸: 非定常造波問題における開境界条件の陽な表現 について, 日本船舶海洋工学会第 2 回推進 ·運動性能合同 研究会資料 (2006) 